The National Oceanographic Data Center is sponsared by U.S. Government agencies having an interest in the marine environment; it is governed by an Advisory Board composed of representatives of these activities and the National Academy of Sciences. The U.S. Naval Oceanographic Office is assigned respansibility for management of the National Oceanagraphic Data Center.

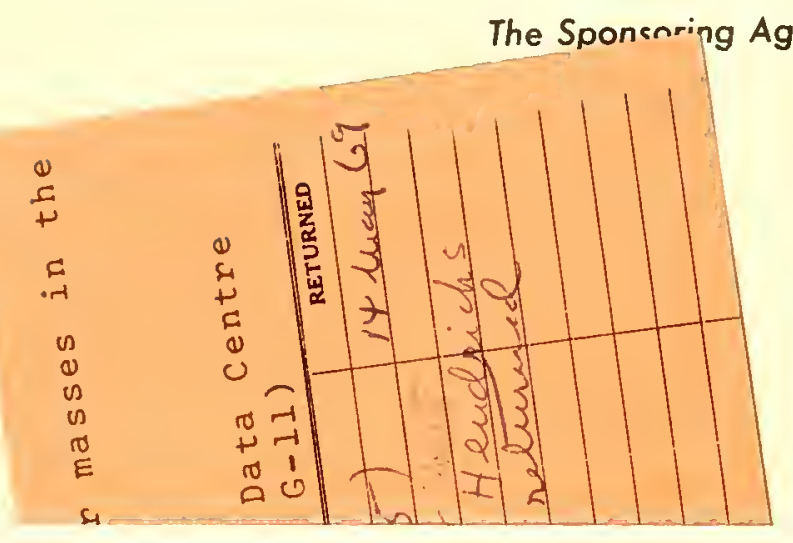

\author{
Atomic Energy Commission \\ Bureau of Commercial Fisheries \\ Coast Guard \\ Coastal Engineering Research Center \\ Department of the Novy \\ Environmental Science Services Administration \\ Federal Water Pollution Control Administration \\ Geological Survey \\ Health, Education \& Welfare \\ National Science Foundation
}

Prinied, by

U. S. Naval Oceanographic Office

Woshington, D. C.

1966 


\title{
NATIONAL OCEANOGRAPHIC DATA CENTER
}

\author{
GENERAL SERIES
}

\section{THE VARIABILITY OF WATER MASSES}

\author{
IN THE \\ INDIAN OCEAN
}

By

\section{JAMES F. GALLAGHER}

Submitted to the Faculty of the College of Arts and Sciences of The American University in Portial Fulfillment of the Requirement for the Degree of Master of Science

\section{PUBLICATION G-11}

\author{
1966
}




\section{ACKNOWLEDGEMENTS:}

Dr. Matthew F. Norton and Prof. Paul S. Baver of The American University for advisory assistance and Mrs. Annette Farrall for typing. 


\section{PREFACE}

It is intendea by this study to trace the areal extent of the principal water masses in the Indian Ocean and the manner in which these watex masses undergo change as they proceed from the area in which they were fomled. These changes are accomplished either through mixing of adjacent water masses or as a result of climatic enviromental variations.

The opintons and conclusions of various authors who have made studfes of the Indian Ocean are included in the sections describing different parts of the ocean. In adaition, the ocean station data contained in the archives of the National Oceanographic Data Center have been analyzed to trace the boundaries of water masses. The temperature-salinity diagrams which are presented at the end of the chapters are for selected representative stations and do not include all stations used in the analysis. The stations were selected on the basis of reliability. Most stations were taken from cruises more recent than 1958, aithough in some instances early cruises, such as the Dana Expedition of 1929, were employed. The stations used to illustrate the temperature-salinity variations are arranged by geographic locations into intersecting cross sections, which show the transition from one water mass to another. In zones of rapid transition the stations are spaced at closer intervals along the 
cross section lines than in areas where there is little change in the water mass. Along some of the section lines the spacing is less than ideal because of a lack of reliable data in particular localities.

A description of the water masses ir the Red Sea and Persian Gulf is not included here, although the influence of these water masses is mentioned as they pertain to other parts of the Indian Ocean.

The first two digits of the NODC cruise numbers, which are listed in the tables of stations, indicate the country of cruise origin. The following country codes are included among the cruises which furnish stations to make up the intersecting cross sections: 09, Australia; 26, Denmark; 31, United States; 35, France; 68, Portugal; 74, United Kingdom; 90, Soviet Union; and 91, South Africa. 


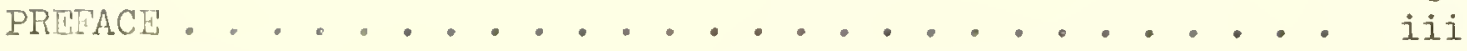

IIST OF TABLFIS ........................... vi

LIST OF ILLUSTRATIONS . . . . . . . . . . . vii vi

Chapter

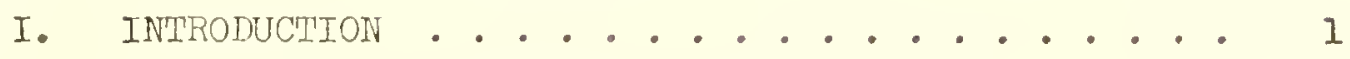

Short History of Fxploration

International Indian Ocean Expedition

II. ARABIAN SEA ................. 7

Circulation

Layer of Mininum Oxygen

Surface Water Properties

Subsurface Water

Internediate Water

Deep Water

Temperature-Salinity Diagrams

III. THE NORTHEAST MONSOON REGION ........ 24

Circulation

Surface Water Properties

Subsurface Water

Deep Water

Temperature-Salinity Diagrams

IV. CENTRAI, AND SOUTHERN INDIAN OCEAN ....... 46

Circulation

Surface Water Properties

Subsurface Water

Internediate Water

Deep Water

Bottom Water

Tlemperature-Salinity Diagrams

V. SUMTARY AND CONCLUSION ................ 68 BIBLIOGRAPHY ................... 73 


\section{LIST OF TABLES}

Table

1. Station Identification for Section $\mathrm{AA}^{\prime}$. . . . . . . . 19

2. Station Identification for Section $\mathrm{BB}^{\prime} \cdot . . . . . . .20$

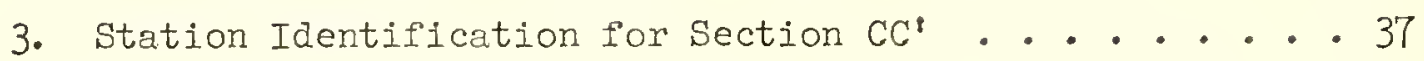

4. Station Identification for Section $\mathrm{DD}^{\prime}$. . . . . . . 38

5. Station Identification for Section EE' . . . . . . 39

6. Station Identification for Section $\mathrm{FF}^{\prime}$......... . 40

7. Station Identification for Section GG' ....... . . 61

8. Station Identification for Section HH' . . . . . . . 62

9. Station Identification for Section JJ' . . . . . . . 63 
Figure

Page

1. Surface Currents in the Arabian Sea for October ... . 17

2. Surface Currents in the Arabian Sea for November . . . 17

3. Surface Currents in the Arabian Sea for December . . . 18

4. Surface Currents in the Arabian Sea for January . . - 18

5. Station Locator Chart for Sections $\mathrm{AA}^{\prime}$ and $B \mathrm{~B}^{\prime} \cdot$. . . $^{\prime} 21$

6. Temperature-Salinity Graphs for Section $\mathrm{AA}^{\prime}$. . . . . . 22

7. Temperature-Salinity Graphs for Section $\mathrm{BB}^{\text {' }}$. . . . . 23

8. Surface Currents in the Northeast Indian Ocean for August . . . . . . . . . . . . . . . . . 35

9. Surface Currents in the Northeast Indian Ocean for February . . . . . . . . . . . . . . 36

10. Station Locator Chart for Sections CC', DD', EE', and $\mathrm{FF}^{\mathrm{P}}$. . . . . . . . . . . . . . . 41

11. Temperature-Salinity Graphs for Section CC' . . . . . 42

12. Temperature-Salinity Graphs for Section DD' . . . . . 43

13. Temperature-Salinity Graphs for Section E' . . . . . 44

14. Temperature-Salinity Graphs for Section FF' . . . . . 45

15. Surface Currents in the Southexn Indian Ocean ..... 60

16. Station Locator Chart for Sections $\mathrm{GG}^{\prime}, \mathrm{HH}^{\prime}$, and $\mathrm{JJ}^{\mathrm{*}}$. 64

17. Temperature-Salinity Graphs for Section GG' . . . . . 65

18. Temperature-Salinity Graphs for Section $\mathrm{HH}^{\prime}$. . . . . 66

19. Temperature-Salinity Graphs for Section JJ' . . . . . 67

20. Water Mass Boundaries . . . . . . . . . . . . 72 
INTRODUCIION

Although the Indian Ocean occupies about 28,000,000 square miles and covers 14 percent of the earth's surface, it is still the least known of the three major oceans. However, exploration of this ocean began at a much earlier date than in the Atlantic or Pacific Oceans.

Short History of Exploration. Indian sallors crossed the northern part of the ocean and established regular trade relations with Egypt, Ethiopla and the Arab countries. The Arabs in turn covered the same routes to visit the ports of India, Africa and the Persian Gulf. Durlng these voyages, both the Indian and Arab sallors carefully studied the winds and currents of the northern part of the ocean for navigational purposes.

The early voyages of Indian, Arab, and later Chinese sallors were confined to the northern part of the ocean and when south of the Equator, they always remained close to the coast. The southern part of the ocean was belleved to be enclosed by land and the southern coast of Afrlca appeared on maps as an extension of Australia. Not until 1487 was this conception dispelled by the voyage of Bartholomew Diaz who went around the southern tip of Africa Into the Indian ocean. Later, in 1497, Vasco da Gama confirmed the connection between the Atlantic and Indian Oceans by salling around the southern part of Africa from the west and continuing on up the coast to visit the ports of India. The Dutch navigator Tasman proved, in 1642, that the Indian Ocean was also jolned to the Paclfic by passing around Australia to the south. 
The great southern extent of the Indian Ocean was established by Captain Cook in 1772 - 1775, although he falled to reach the continent of Antarctica. A point of interest about Cook's voyage is the fact that he was the first to take deep ocean temperatures. Three observations of temperature in the Indtan Ocean were made in the high southern latitudes at about 200 meters depth.

A new phase in oceanographic research was initiated in 1873 by the Challenger Expeaition ${ }^{2}$ which accounted for 13 deep stations In the southern part of the Indian Ocean. This was the first time that an expedition had been organized specifically to take complex oceanographic surveys. Observations were made for temperature, speciflc gravity, and chemical elements. Before this time oceanographic observations had been made princlpally for temperatures in the deep water.

In the early part of the Twentieth Century research in the Indian Ocean Included 89 stations taken by the German ship Planet ${ }^{2}$ In 1906 and 59 stations taken during the Dana Expedition ${ }^{3}$ of 1929 in the northern and western parts of the ocean. On the basis of all data avallable througn 1929, I. Möller ${ }^{4}$ was able to formulate the broad circulation pattern of the Indian Ocean and to describe the principal water mass structure in the south-central part of

${ }^{1}$ W1IIiam Spry, Cruise of Her Majesty"s Ship Challenger (London: Low, Marston, Searie, and Rurington, 1877).

${ }^{2}$ Reichs-Marine amt., Expedition of S.M.S. Planet, 1906-0T (Beriln: Sigismund, 1909).

${ }^{3}$ Carlsberg Foundation, oceanographic Expedition around the Norld (London: Oxford University Press, 1932). 1933)

4. Möller, Deep Sea C1rculation in the Indan Ocean Hamburg: 
the ocean. She divided the ocean into four layers: (1) a subsurface laver of subtropical origin, resting on (2) a freshened intermediate layer of Antaxctic origin; below this layer is (3) a warm, saline deep layer which circulates toward the south; and, finally (4) there is again on the sea-bottorn, cold Antarctic water alrected toward the north. It was also polnted out by Mölier that in the eastem part of the ocean the Antarctic Intermediate Current is much better developed than in the west. On the western side there is. predominance of a warm, deep current coming from the Arabian Sea.

Ocean survey expeditions in the Indian Ocean were suspended by WorId War II and It was not until 1948 that observations were renewed by the Swedish cruise of the Albatross III $^{1}$ which occupied 30 deep sea stations in equatorial latitudes. Much information was gained from data obtained on this cruise concerning the Equatorial Counter Current during the winter season of the Northern Hemisphere. In February this current covers a zone between $6^{\circ}$ and $8^{\circ} \mathrm{s}$. latitude and reaches a maximum velocity of $22 \mathrm{~cm} / \mathrm{sec}$ at a depth of 75 meters. Oceanographic data obtained by the Norsel I and Norsel II during 1955-56 were studied by P. Tchernia ${ }^{2}$ to determine the dynamic structure of currents of the North Equatorlal section of the Indian Ocean. He constructed meridional cross sections mainly in the winter monsoon season and none were made in the summer monsoon.

\footnotetext{
${ }^{1}$ Svenska djupharsexpeditionen, Reports edited by Hans Petterssor. (Goteborg: Elenders boktr., 1951).

${ }^{2}$ P. Tchernia, H. Lacombe, and P. Guibout, "Some New Hydrological Observations in the Equatorial Region of the Indian Ocean"; France, Bulletin d' Information, X(3)(March 1958), pp. 115-143.
} 
Charts were constructed to show the location of intermediate and Antarctic waters.

International Indian Ocean Expedition. Indian Ocean exploration and research had been carried on independently by national governments or private institutions up until 1957. In that year the idea for international cooperation and large-scale oceanographic study of the entire ocean was first considered. The task of developing a coordinated plan of study was given to the Special Committee on Oceanic Research (SCOR) which is affiliated with the International Council of Scientific Unions (ICSU).

The Scientific Committee on Oceanic Research appointed Mr. Robert Snider (U.S.A.) as its International Indian Ocean Expedition (IIOE) coordinator. Mr. Snider visited various countries to stimulate interest and to develop plans for their participation. 'The following is a list of participating countries:

Ship operating countries: Australia, France, Germany (Fed. Rep.), India, Indonesia, Japan, Pakistan, Portugal, Republic of South Africa, Thailand, Soviet Union, United Kingdom, and United States.

Other participants: Burna, Ceylon, China, Ethiopia, Israel, Italy, Malagasy Republic, Federation of Miaya, Mauritius, and Sudan.

Late in 1960, the United Nations Educational, Scientific and. Cultural Organization (UNTSCO) agreed to co-sponsor the sypedition

${ }^{I}$ United Nations Educational, Sciertific and Cultural Organization, "Developnert of the Intenntional Indian Ocean Expedition"; Collected Reprints of the International. Indian Ocean Expedition (Bruges: St. Augustin Press, 1965). 
and to provide certain facilities which were necessary to such a large international undertaking. Special customs agreements were arranged and courtesies were provided for ships and personnel taking part in the expeditior. Within the framework of UNFSCO, the Intergovernment l oceanographic Comission (IOC) and the office of Oceanography were established and coordination of the expedition was assumed by the IOC secretary. This coordination is maintained through working groups and through the IOC Information Paper which is issued by UNESCO. Participating nations supply information of their activities through national coordinators for IIOE.

SCOR remained responsible for the advisory aspects of the expedition and a small group of scientific specialists were appointed as disciplinary experts for the expedition: Professor J. Krey (Germany): phytoplankton, zooplankton, primary production, pigments; Professor L. A. Zenkevich (U.S.S.R.): benthos, mid-water and deep fauna; Professor P. Tchernia (France): aynamics and circulation, chemistry.

In addition Dr. R. I. Fisher was requested to advise on the geological and geophysical aspects of the expedition. These experts were required to review and evaluate IIOE programs in their respective fields.

An international sorting station for zooplankton was developed on the advice of the IIOE biological working group. This station is known as the Indian Ocean Biological Center and was established in 1963 at Ernakulam, South India. Participating ships send samples which are taken in a standard IIOE net to the center for sorting and later analysis. 
The International Meteorological Center was set up at Bombay as a result of a meeting of SCOR and IOC 1n 196I. It is administered by the World Meteorological Organization (WMO) under a United Nations Special Fund Project. Dr. C. Ramage was appointed as International Scientific Coordinator for Meteorology with headquarters in Bombay. Airplanes and buoys are used to study the atmospheric circulation related to the monsoons and to investigate the energy exchange between ocean and atmosphere. ${ }^{1}$

Special care was used to standardize methods and intercalibrate the instruments used by participants in IIOE in order to make the observations more reliable and more comparable. Reference stations were estabiished at fifteen locations throughout the Indian Ocean where participating ships could take observations, whenever possible, for the purpose of intercalibration and comparison of working methods.

Copies of all the data connected with the IIOE are to be deposited in the two World Data Centers for Oceanography (Washington and Moscow) and will be used for compilation of charts and atlases of the Indian Ocean.

\footnotetext{
1 Ibid.
} 
Aside from 1ts characteristic high temperature and high salinity relationship, two other features are present. in the Arabian Sea which distinguish it from all other parts of the Indian Ocean. One ig the seasonal reversal in circulation which is induced by the monsoons and the other is the layer of minimum oxygen which is found below the surface waters.

Circulation. In the northern part of the Indian Ocean the surface currents are inftiated by the monsoon winds and vary in direction with the seasons. In the Arabian Sea the northeast monsoon preva1ls in the winter, being replaced in summer by the southwest monsoon. Of the two monsoons the southwest endures over a much longer period of the year, is stronger and steadier than the northeast one. The surface currents induced by these winds are a source of confusion for mariners who lack the experience of salling in these waters. The U. S. Hydrographic office has produced charts based on thousands of observations which show the monthly and seasonal variations of these currents. The accompanying charts (Figs. 1-4) which are based on the Hydrographic Office's charts ${ }^{1}$ illustrate the fall transition from southwest to northeast monsion circulation.

The fall transition takes from about the first of october and usually lasts to the end of November. The northeast (fine weather monsoon) is in force during the months of December and January.

"Pilot Chart of the North Pacific Ocean No. 1401, "Currents in the Arabian Sea" on reverse side, (U. S. Hydrographic office, Washington, D. C., June 1956). 
The spring transition begins about the middle of February and Iasts through the month of April. By the midale of May the current patterns of the southwest monsoon are established. The winds continue to increase gradually unt11 June when there is a "burst" or sudden strengthening of the southwest winds. During July and August the winds cont1nue at their greatest strength unt11 September when the force decreases in preparation for the fall transition which lasts through october and November. The annual cycle of the monsoon begins anew in December when the northeast circulation pattern is again in force.

During the northeast monsoon period the currents in the Arabian Sea and the northern Indian Ocean set roughly in a westerly and counterclockwise direction and during the southwest period the currents are set easterly and in a clockwise rotation. The easterly and westerly directions are direct monsoon currents and the clockwise and counterclockwise rotations are set up during the periods of transition when the winds are varlable. In addition two very important streams feed Into the currents of the Arabian Sea: the north-fllowing East African Current during the southwest monsoon, and the westerly setting stream which passes around Ceylon during the northeast monsoon. Because these streams develop ahead of the general east and west drifts in the Arabian Sea and exert pressure on the waters of the sea, they help to explain the peculiar currents observed during the transition periods. The coastal currents follow the coastal contours, flowing northerly along the Arabian coast and southerly along the Indian coast during the easterly drift and reverse themselves during the westerly drift. 
The East Drift is of longer duration, more stable and stronger than the West Drift. Likewise the counterclockise circulation of the fall transition is less well defined and Is weaker than the clockwlse circulation of the spring transition. The counterclockwise circulation can hardy be identified without including the noxthern Indian Ocean in the diagram.

The currents of the Arabian Sea reach their greatest velocities during July and August and the highest maximum and mean velocities are attalned in the vicinity of the island of Socotra. The coastal currents are stronger and more stable than those which occur in the open sea during any particular period.

The seasonal reglme of currents in the Arabian Sea can be divided into four periods as follows: (1) the spring transitional period of February, March and April; (2) the period of the East Drift during May, June, July, August, and September; (3) the fall transitional period of October, November, and December; and (4) the period of the West Drift during January. ${ }^{1}$

Below the surface layer in the depths from 150 - 400 meters the circulation in the Arabian Sea is determined by the difference In water densities which exist in different sections of the sea. The action of the wind has only an indirect effect on the subsurface circulation by producing zones of divergence at the surface where deep waters ascend and zones of convergence where the surface waters descend. The general subsurface circulation consists of an anticyclonic gyre in which there is sinking of surface water. The stream of water passing out of the Red Sea through the Gulf of

I Ibid. 
Aden and water from the Persian Gulf participate in this subsurface circulation. In the southeastern part of the Arabian Sea the subsurface flow has a southern direction and crosses the Equator into the eastern part of the ocean. At approximately $70^{\circ}$ East part of the circulation bends eastward and continues on into the Bay of Bengal. Layer of Minimum Oxygen. The tropical subsurface layer of minimum oxygen has been described in reports of the John Murray Expedition ${ }^{1}$ of 1933-34. Of all tropical seas this layer is most pronounced in the Arabian Sea where the oxygen content almost disappears at middepth. The Russian vessel Vityaz reported a complete lack of oxygen from a depth of 250 meters to the bottom (832 meters) in parts of the northeast sector. The low oxygen content also extends to the surface and the $\mathrm{pH}$ content, having the same distribution pattern as $\mathrm{O}_{z}$, reaches the smallest values in the Arabian Sea $(7.64-7.67)$. Another peculiarity of this sea is the existence of $\mathrm{H}_{2} \mathrm{~S}$ in the intermediate waters over an extensive area. ${ }^{2}$ An earlier expedition of the vessel Mabahiss had reported $\mathrm{H}_{3} \mathrm{~S}$ in the near-bottom layer near the entrance of the Gulf of Oman and near Bombay.

The layer of mintmum oxygen is most usually found in the northern part of the Arabian Sea at a depth of 75 meters, but toward the Equator it descends to a depth of 150 meters. According to Schott $^{3}$ the layer of minimum oxygen is most pronounced off Bombay, where it is generally found at the depth of 50 meters. Although

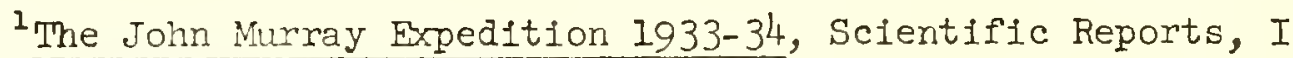 (London: 1935).}

${ }^{3}$ P.I. Bezrukov, "Investigations in the Indian Ocean on the 33rd Cruise of the Expeditionary VesseI Vityaz," Trans. okeanologiya, Vol. I, No. it (Moscow: 1961).

${ }^{3} \mathrm{G} \cdot$ Schott, Geographie des Indischen und Stilien Ozeans (Hamburg: Boysen, 1935). 
salinity is relatively high in this layer, 35.5 to 36 per mille, the salinity maximum is found slightly below it. A high nitrite concentration, probably the highest in the world ocears, 1s also associated with the minimura oxygen of the Arablan Sea. The upper boundary of the layer is relatively sharp and coincides with the sharp thermocline which varies with the seasonal upwelling or coastal plling up of surface waters according to the prevailing monsoon. Mass mortality of fish has been reported along the Arablan and Indian coasts in seasons when upwelling of the layer of minimum oxygen is to be expected. Such mass mortality might very well be caused by the lethal effect of the low oxygen content or in conjunction with the accompanying "red tides."

Some investigations off Bombay sponsored by the United Nations Educational, Scientific and Cultural Organization in October and November of $1958^{2}$ found the layer with an average oxygen content of $0.7 \mathrm{ml} / 1$. occurring at an average depth of about 18 meters some 18 nautical miles out from the coast. During this season the layer of minimum oxygen is expected to approach the surface under the Influence of the upwelling near Bombay which is caused by the direction of the monsoon wind. The slope of the discontinuity layer was upward toward the coast and intersected the bottom at about 7 fathoms. The phosphate content in the layer of minimum oxygen was relatively high (greater than 1 ugm. at./liter.). The salinity was about 36.0 per mille and the temperature around $24^{\circ} \mathrm{C}$. The upper boundary of the layer seems to rise and fall with the

IDr. J. W. Carruthers, S. S. Gogate, J. R. Naidu, and T. Laevastu, "Shoreward Upslope of the Layer of Minimum Oxygen off Bombay," Nature, CXXCIII(4668), 1084-1087 (Apr. 18, 1959). 
tides causing an up and down migration of the fish. During the southwest monsoon the mixed surface layer will be rather thick off Bombay and the minimum oxygen correspondingly deep due to the piling up of surface waters. During the northeast monsoon the minimum oxygen layer w1ll gradually ascend to shallower depths because the surface water will be blown seaward and cause upwelling from below. A rich plankton bloom is associated with the upwelling; however, the tuna and sardines do not come into the area to feed on the plankton. They remain outside the upwelling zone because of the low oxygen content of its water.

The orlgin of the layer of minimum oxygen in the Arabian Sea is not yet fully understood, but it is associated with a high salinity and high temperatures and for this reason many authors believe that It orlginates through the outflow f'rom the Red Sea and Persian Gulf. Surface Water Properties. The surface water of the Arabian Sea generally occupies the layer from the surface to a depth of 100-150 meters, although In some areas where seasonal upwelling occurs the normal surface water is replaced by water which rises from the subsurface. The average temperature in the surface layer ranges from $20^{\circ} \mathrm{C}$ to $29^{\circ} \mathrm{C}$ varying according to the seasons. The highest surface temperature in the Indian Ocean, excluding the Red Sea and Persian Gulf, is found in the northern sector of the Arabian Sea during summer. Here the surface temperature will reach $30^{\circ} \mathrm{C}$ during August. In winter, under the Influence of the northeast monsoon, the surface temperature in the northern peak will drop to $22-23^{\circ} \mathrm{C}$. The summer monsoon causes upwelling in the flow of the relatively cool waters of the Somali Current along the African and Arabian coasts. This 
process reduces the surface temperatures along these coasts. The upwelling is more intense along the African coast than along the Arabian coast, and corresponding surface temperatures are $21^{\circ} \mathrm{C}$ In the region of Cape Ras Khafun, and $23^{\circ} \mathrm{C}$ near the coast of Arabia. The greatest salinity value north of the Equator on the surface of the Indian Ocean occurs in its western part which includes the Arabian sea where surface salinities exceed $36.5 \%$ in its northern part. In the surface layer of the Arabian Sea salinity varies from 35.8 to over $36.5 \%$. Precipitation falls almost exclusively in the western part of the sea during the winter monsoon. On the other hand, during the period of the summer monsoon, precipitation falis in the eastern part near the mountainous coast of Hindustan. The indicated amount of precipitation over the entire surface of the Arabian Sea is considerably less than the evaporation and this deficit of precipitation determines the significant increase in salinity of the surface water. ${ }^{2}$

Great evaporation in the Arabian Sea under conditions of high temperature results in an increase in salinity. This condition causes an increase in density of the surface water which exceeds 24.0 $\sigma_{t}$ during the course of a year. Near the Arabian peninsula in sumer the surface density value reaches $24.5 \sigma_{t}$. Sigma-t $\left(\dot{\sigma}_{t}\right)$ is a shortened expression for the density of sea water and is defined by: $\sigma_{t}=\left(\mathrm{gms} / \mathrm{cm}^{3}-1\right) \times 1000$

The oxyen content in the surface layer down to about 50 meters equals $3.94-4.75 \mathrm{ml} / \mathrm{l}$. This corresponds to a saturation value of

${ }^{1}$ A. M. Muromtsev, Basic Outline of the Hydrology of the Indian Ocean (Leningrad: 1959), pp. 84-90. 
$82-103 \%$. In the lower depths of the layer the oxygen content drops sharply to $1.13-2.39 \mathrm{ml} / 1$. and a saturation value of $22-$ $60 \%$

Subsurface Water. From immediately below the surface layer the subsurface layer extends to a depth of about 400 meters in the Arabian Sea. It is formed in the gulfs of Aden and Oman and in the adjacent part of the Arablan Sea, by the mixing of waters coming from the Red Sea and the Persian Gulf with the surface water of the Arabian Sea. It then sinks in the anticyclonal gyre and partially as a result of winter convection. This water spreads through the entire northern part of the ocean and is bounded near the Equator by a zone of upwelling South Indian Ocean intermediate water. The latter penetrates through the Equator into the western part of the sea and reduces the salinity of the subsurface water of the Arabian Sea. The water coming from the Red sea is identified by a high temperature and salinity of $39.7 \%$ when 1 t reaches the Gulf of Aden. Salinity in the water coming from the Persian Gulf is nearly as high as that from the Red Sea. However, the volume of water from the former is much smaller and therefore does not exert as much influence on the waters of the Arabian Sea. The temperature in the Arabian Sea subsurface water varies from 10 to $19^{\circ} \mathrm{C}$. The salinity ranges from 35.0 to greater than $36.0 \%$ and decreases with distance away from the formation sources near the Persian Gulf and Red Sea. The oxygen content is very low amounting to $0.21-2.09 \mathrm{ml} / 1$, and in some places a complete absence of oxygen is reported. ${ }^{1}$

Intermediate Water. Water from the Gulf of Aden comes into the Arabian Sea at depths of 400 - 600 meters with a salinity of $36.5 \%$ 
Here it is mixed with adjacent water and forms the intexmediate water of the Arabian Sea. The latter fills a layer from 400 1500 meters below the subsurface water. The intermediate water is formed in much the same manner as the subsurface water, except that convection does not play a part. Salinity in the upper part of the intermediate water reaches a Iittle over $36.5 \%$ and decreases to $35.0-35.5 \%$ at depths from 800 to 1500 meters. This water spreads south of the Equator in the western part of the ocean and towara the east it goes into the Bay of Bengal at depths of 500600 meters. At the Equator it is Iimited by the South Indian Ocean Intermediate water, and when it meets with the latter, it is strongly mixed, especially in the eastern part of the ocean. The temperature ranges with depth from about 4 to $13^{\circ} \mathrm{C}$ and the oxygen content is 0.40 to $1.43 \mathrm{ml} / 1$.

The Deep Water. Arabian Sea deep water is formed as a result of mixing of Arabian Sea intermediate water, South Indian Ocean intermedlate water, and Indlan Ocean bottom water. This water maintains a temperature higher than $2^{\circ} \mathrm{C}$ over its entire depth in the Arabian Sea and only at depths greater than 3000 meters in the bottom water do the temperatures drop below this value. The salinities vary from $34.68-34.78 \%$ and the oxygen content is about $3 \mathrm{ml} / 1 .^{1}$

Temperature-Salinity Diagrams. The subsurface water, along with the intermediate water, are the two most characterist1c water masses of the Arabian Sea. The accompanying diagrams (Figs. 6 and 7) serve to outline their approximate horizontal extent before losing their iden'ifying properties. The T-S curves illustrate the changes which take place in the water column with distance from the source regions 
of these water masses. The symbols which appear on the T-S station plots correspond to the symbols which identify the station locations on the chart. In order to show the extent of the typically Arabian Sea water, two sets of ocean stations were selected. The first set extends in a west to east direction beginning in the Gulf of Aden near the Bab el Mandeb Stralt and terminating near the island of Ceylon. The second set of stations are located along a north-south IIne originating in the Gulf of Oman near the entrance to the Persian Gulf. The southernmost station of the second set is located at about $3^{\circ} \mathrm{N}$. The NODC cruise number, station number, ship, and year for each station in the plot are listed in Tables 1 and 2 . From an observation of the T-S plots and station locations it is quite apparent how the Arabian Sea water masses undergo change as they proceed from their region of orlgin. The salinity decreases gradually from west to east and from north to south and the T-S profile for the last station of each set is no longer typical of the Arabian Sea water. Instead these last stations fall within the T-S envelope of the Indian Equatorial water, although they still carry a strong Arabian Sea influence. The boundary of the Arabian sea water was thus determined by the merging of its T-S envelope Into that of typical Equatorial water. 


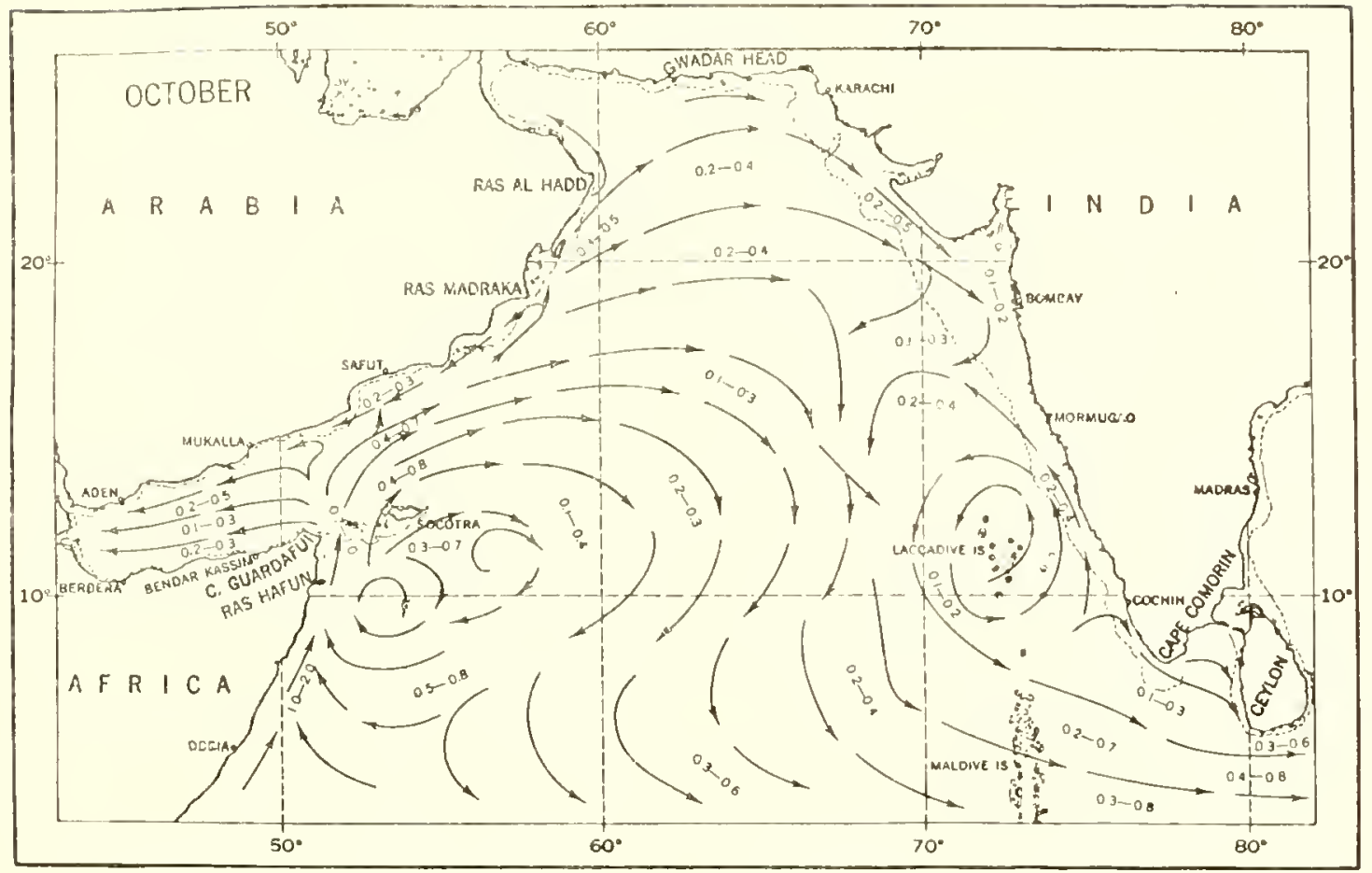

Fig. 1

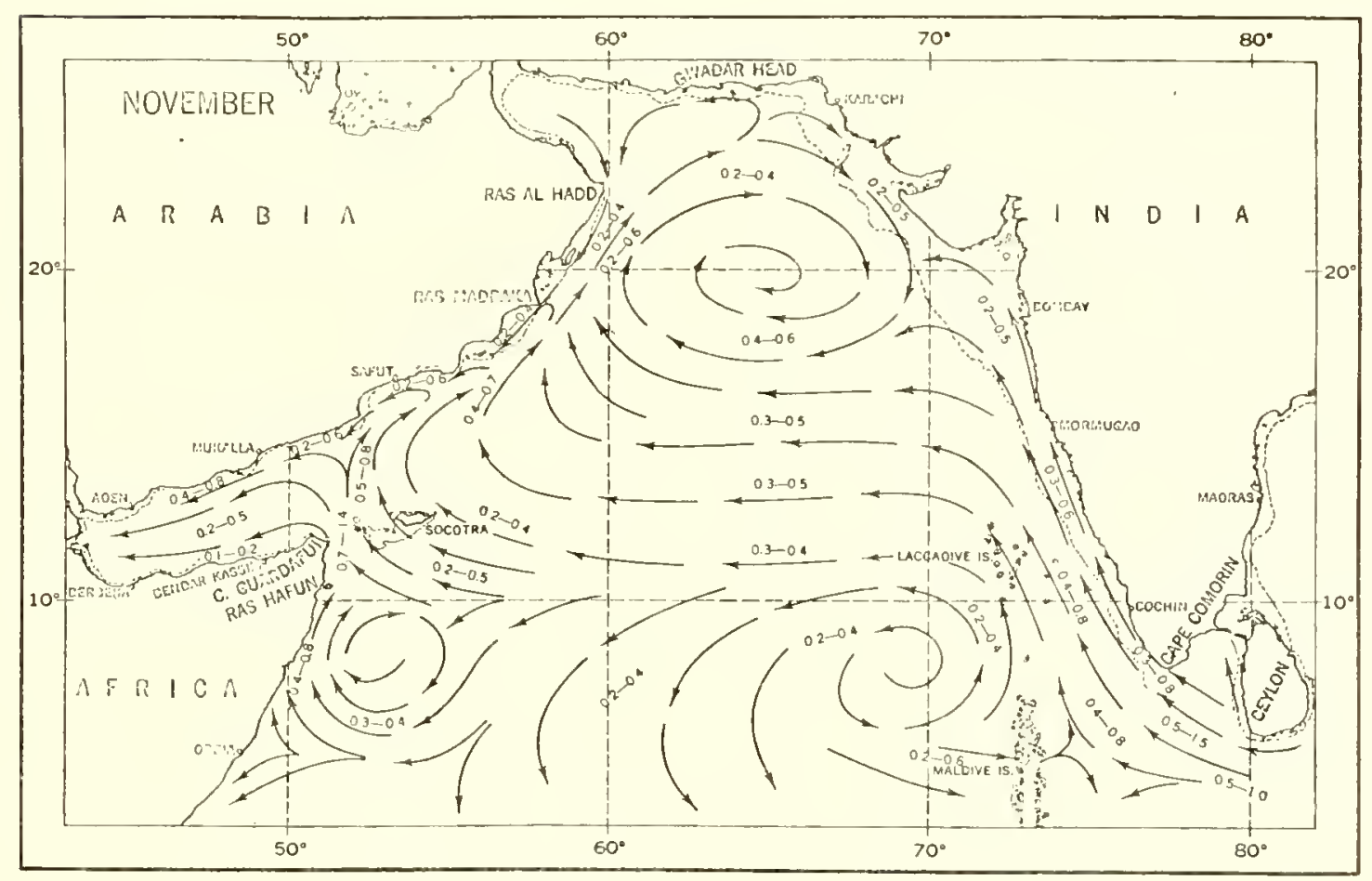

Fig. 2 


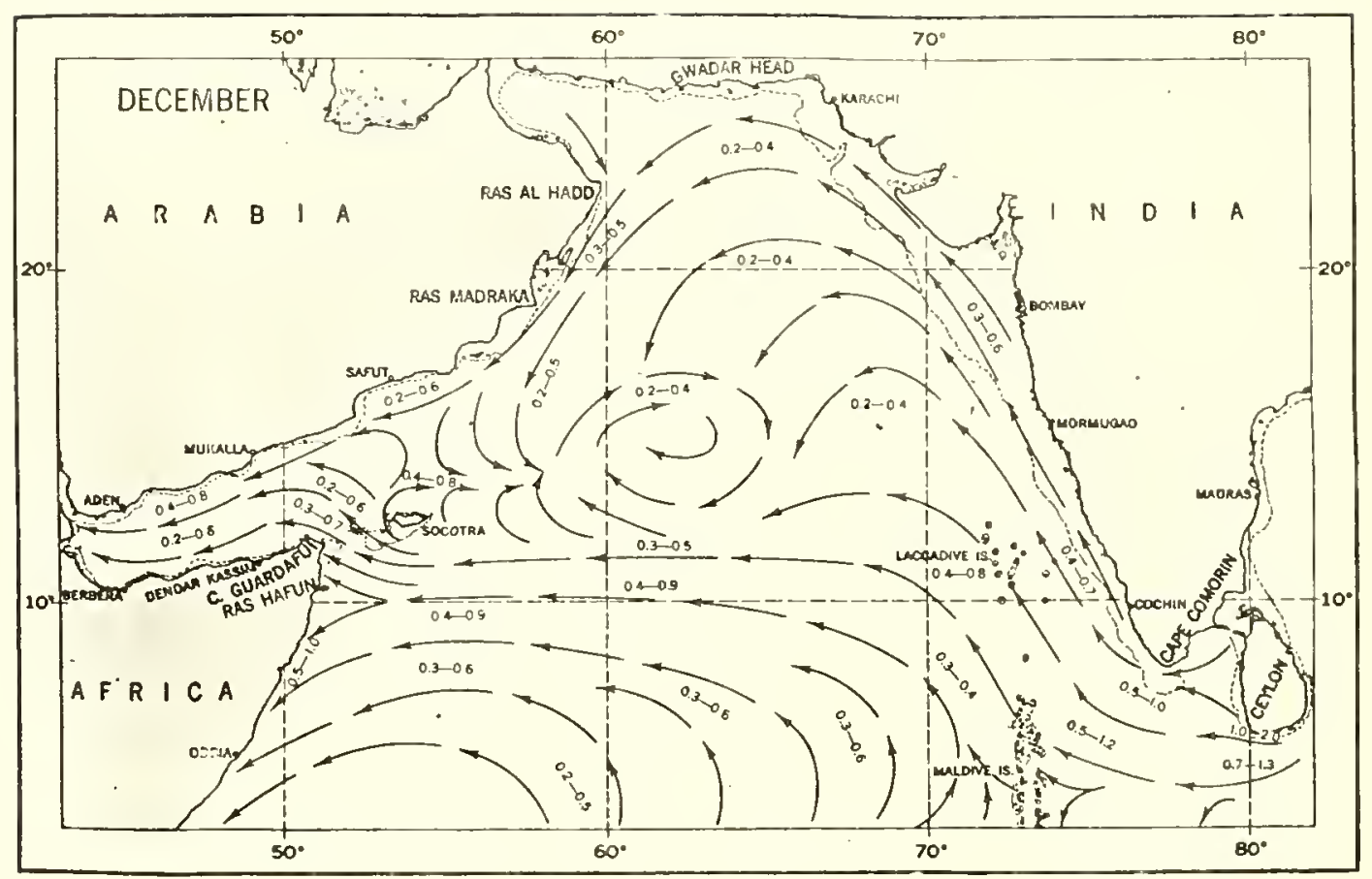

Fig. 3

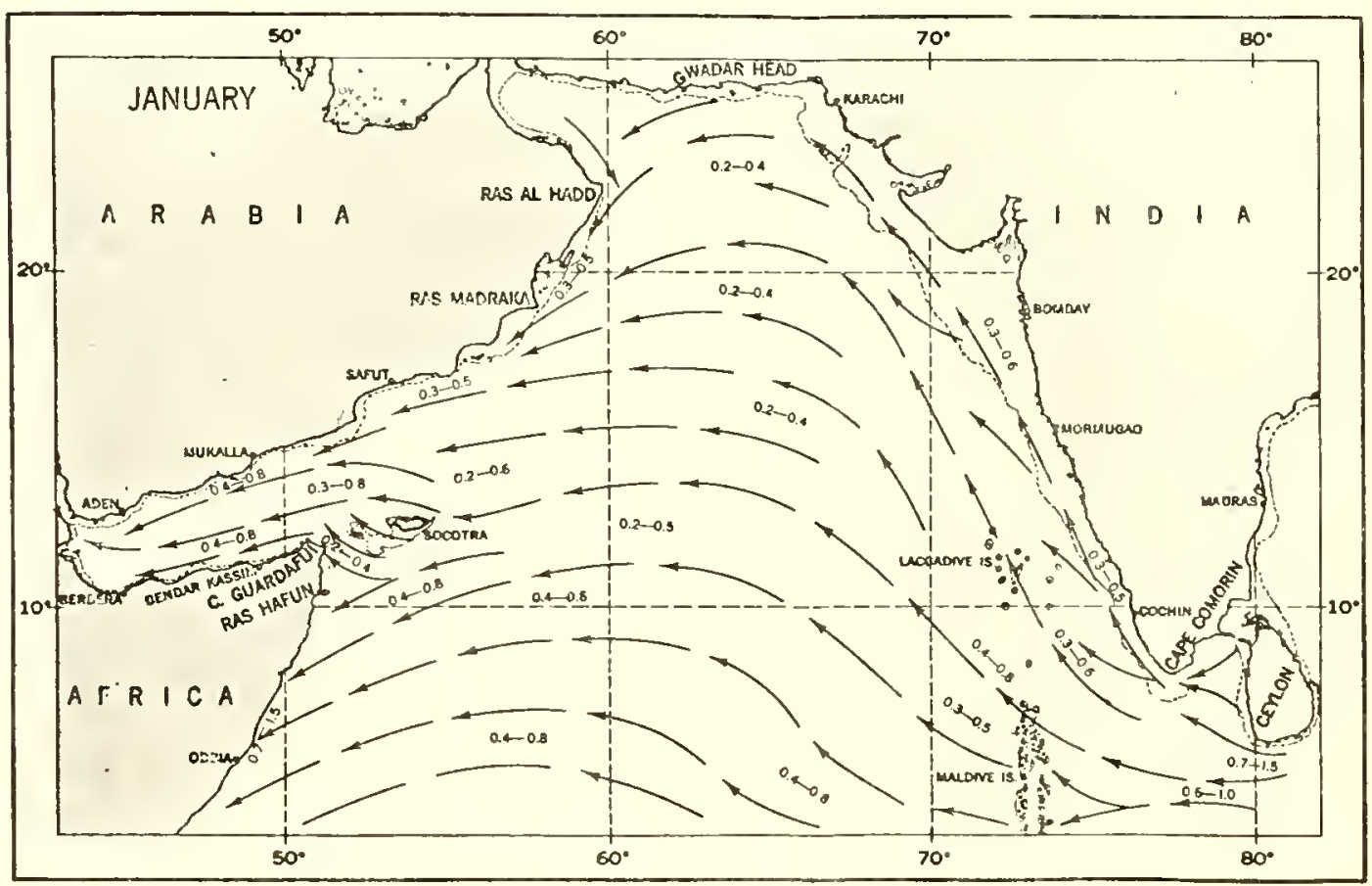

F1g. 4 
ARABIAN SEA WEST TO EAST SECIION AA'

\begin{tabular}{|c|c|c|c|c|c|}
\hline Symbol & $\begin{array}{r}\text { NOIC } \\
\text { Cruise No. }\end{array}$ & $\begin{array}{c}\text { Consec. } \\
\text { No. }\end{array}$ & Coorainates & ShIp & Year \\
\hline$\nabla$ & 31838 & 011 & $\begin{array}{l}12^{\circ} 02^{8} \mathrm{~N} \\
44^{\circ} 14^{\prime} \mathrm{E}\end{array}$ & AILANTIS & 1958 \\
\hline$\forall$ & 31.183 & 027 & $\begin{array}{l}13^{\circ} 17^{\prime} N \\
49^{\circ} 15^{\prime} \mathrm{E}\end{array}$ & HORIZON & 1962 \\
\hline$\otimes$ & 90010 & 205 & $\begin{array}{l}14^{\circ} 33^{\prime} \mathrm{N} \\
56^{\circ} 55^{\prime} \mathrm{E}\end{array}$ & VITIAZ & 1960 \\
\hline$\diamond$ & 90010 & 203 & $\begin{array}{l}16^{\circ} 11^{\prime} \mathrm{N} \\
60^{\circ} 45^{\prime} \mathrm{E}\end{array}$ & VITYAZ & 1960 \\
\hline$\square$ & 90010 & 202 & $\begin{array}{l}16^{\circ} 50^{\prime} \mathrm{N} \\
62^{\circ} 21^{\prime} \mathrm{E}\end{array}$ & VITYAAZ & 1960 \\
\hline$\Delta$ & 90010 & 194 & $\begin{array}{l}15^{\circ} 12^{\prime} \mathrm{N} \\
68^{\circ} 34^{\prime} \mathrm{E}\end{array}$ & VITYAZ & 1960 \\
\hline 0 & 31197 & 091 & $\begin{array}{l}09^{\circ} 60^{\prime} \mathrm{N} \\
74^{\circ} 3 I^{\prime} \mathrm{E}\end{array}$ & ATLANTIS II & 1963 \\
\hline$\theta$ & 90010 & 106 & $\begin{array}{l}07^{\circ} 07^{\circ} \mathrm{N} \\
75^{\circ} 14^{\prime} \mathrm{E}\end{array}$ & VITYAZ & 1960 \\
\hline$x$ & 31090 & 014 & $\begin{array}{l}06^{\circ} 07^{\circ} \mathrm{N} \\
78^{\circ} 05^{\prime} \mathrm{E}\end{array}$ & SERRANO & 1963 \\
\hline
\end{tabular}


ARABIAN SEA NORTH-SOUIH SECIION BB'

\begin{tabular}{|c|c|c|c|c|c|}
\hline Symbol & $\begin{array}{c}\text { NODC } \\
\text { Cruise No. } \\
\end{array}$ & $\begin{array}{c}\text { Consec. } \\
\text { No. }\end{array}$ & Coordinates & Ship & Year \\
\hline$\nabla$ & 74005 & 041 & $\begin{array}{l}25^{\circ} 12^{8} \mathrm{~N} \\
57^{\circ} 17^{\prime} \mathrm{I}\end{array}$ & MABAHISS & 1933 \\
\hline$\theta$ & 31865 & 176 & $\begin{array}{l}23^{\circ} 29^{\prime} \mathrm{N} \\
61^{\circ} 30^{\circ} \mathrm{E}\end{array}$ & REQUISITE & 1961 \\
\hline$\triangle$ & 31865 & 184 & $\begin{array}{l}23^{\circ} 27^{\prime} \mathrm{N} \\
63^{\circ} 35^{\prime} \mathrm{E}\end{array}$ & REQUISITE & 1961 \\
\hline$\diamond$ & 31865 & 158 & $\begin{array}{l}20^{\circ} 29^{\prime} \mathrm{N} \\
64^{\circ} 33^{8} \mathrm{E}\end{array}$ & REQUISITE & 1961 \\
\hline$x$ & 90010 & 201 & $\begin{array}{l}17^{\circ} 35^{\prime} \mathrm{N} \\
64^{\circ} 09^{\prime} \mathrm{E}\end{array}$ & VITYAZ & 1960 \\
\hline$\otimes$ & 74005 & 051 & $\begin{array}{l}12^{\circ} 08^{\prime} \mathrm{N} \\
63^{\circ} 05^{\prime} \mathrm{E}\end{array}$ & MABAHISS & 1933 \\
\hline 0 & 31183 & 028 & $\begin{array}{l}09^{\circ} 40^{2} \mathrm{~N} \\
66^{\circ} 19^{\prime} \mathrm{E}\end{array}$ & HORIZON & 1962 \\
\hline$\triangle$ & 74005 & 081 & $\begin{array}{l}06^{\circ} 55^{\prime} \mathrm{N} \\
67^{\circ} 11^{\prime} \mathrm{E}\end{array}$ & MABAHISS & 1933 \\
\hline$\square$ & 90010 & 114 & $\begin{array}{l}03^{\circ} 11^{8} \mathrm{~N} \\
67^{\circ} 02^{8} \mathrm{E}\end{array}$ & VITYAZ & 1960 \\
\hline
\end{tabular}




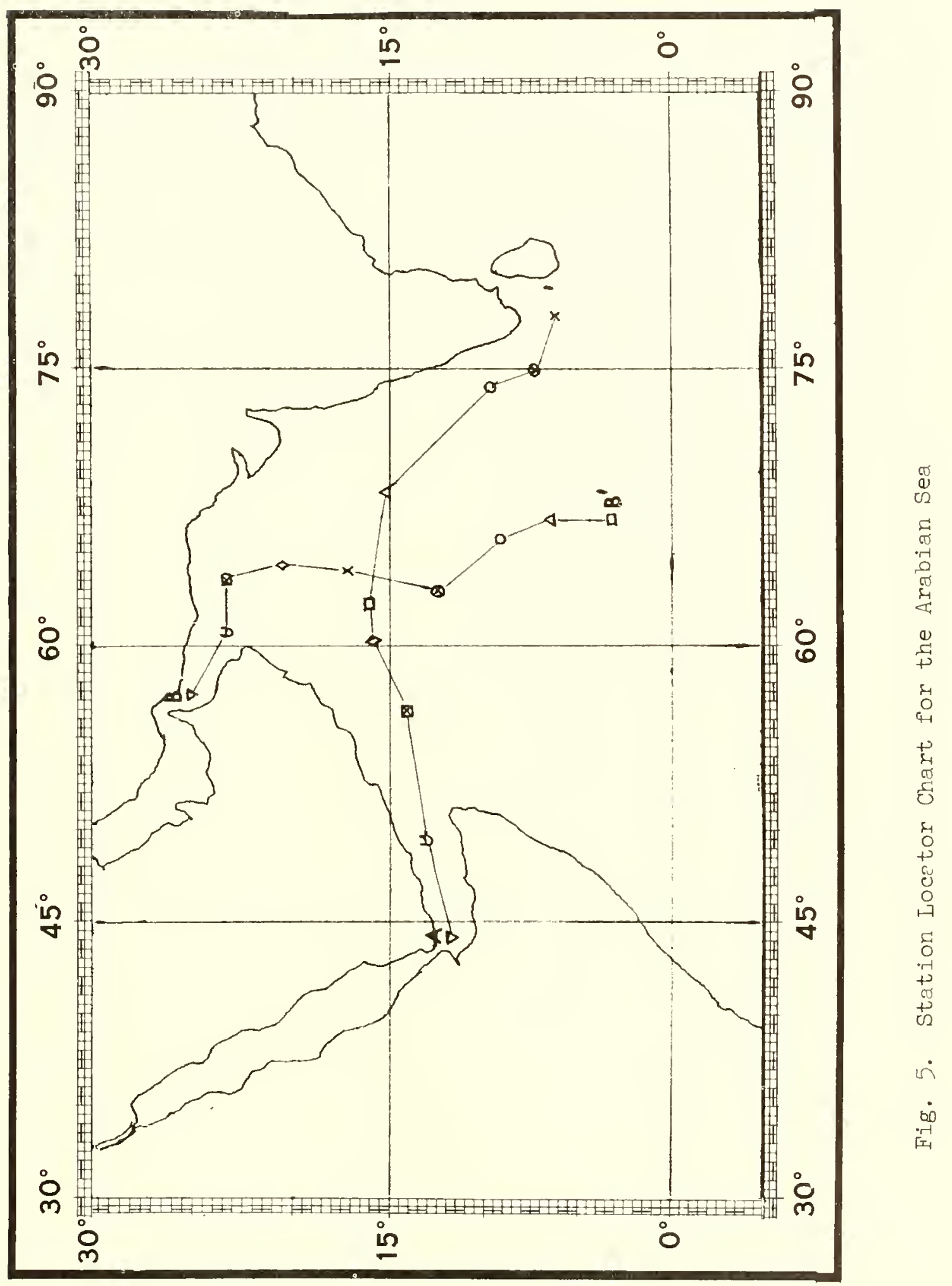




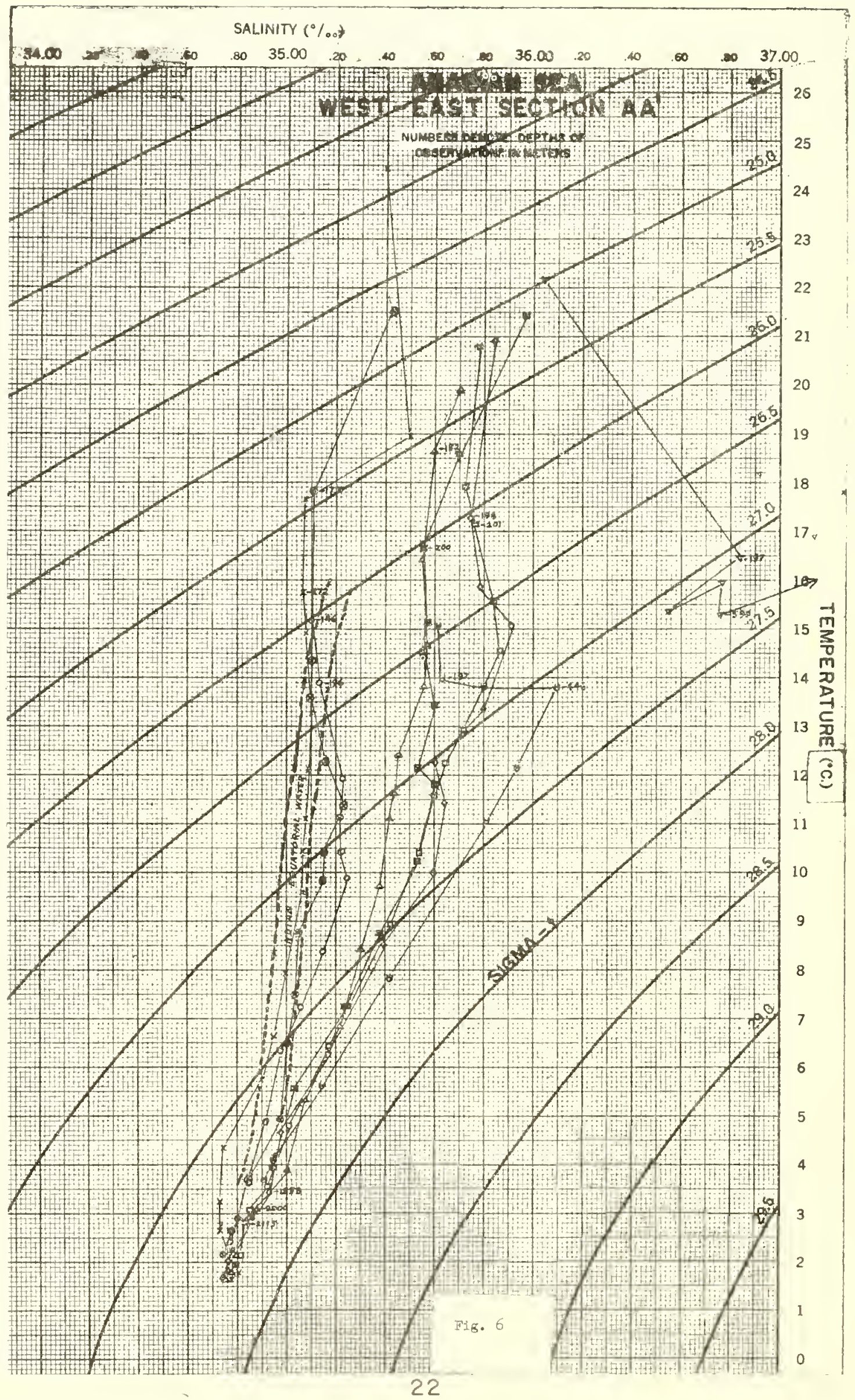




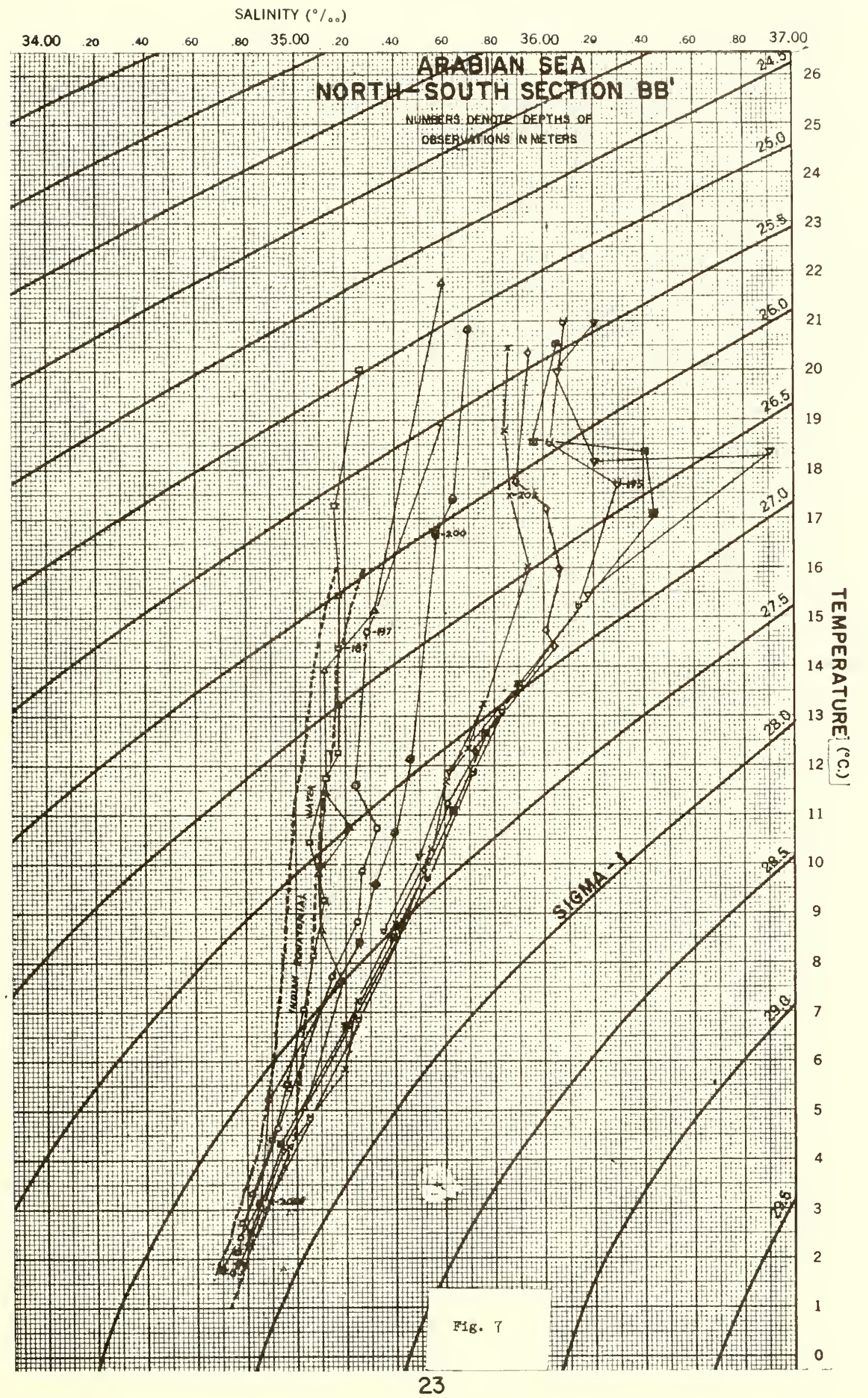


THE NORTHEAST MONSOON REGION

The Bay of Bengal and the Indo-Australian Basin together comprise the monsoon region of the northeast Indian Ocean. Here, as in the Arabian Sea, the seasonal changes in direction of the monsoon winds dominate the circulation pattern and the characteristics of the surface water. A striking difference, though, is the far greater amount of precipitation which occurs in this region compared to the Arabian Sea.

Circulation. The changing monsoons over the northern part of the Indian Ocean cause an alternating current system with a yearly cycle. From June to October a strong northeast drift current is developed north of the Equator as a result of the southwest monsoon which blows with considerable strength toward Burma. The northeast drift extends across the Bay of Bengal and leads to an extremely high piling up of water along the eastern side of the bay during June. Part of this water escapes by flowing south through the Andaman sea and around the west corner of Sumatra. A smaller part turns north and sets up a cyclonic gyre in the northern part of the bay which lasts from July to October. As a result of the gyre a southerly set current is created along the northeast coast of India which meets the northerly set current which flows along the Madras Coast. ${ }^{1}$ In the southerm part of the bay between about $5^{\circ} \mathrm{N}$ and $10^{\circ} \mathrm{N}$ the monsoon current is set strongly toward the east during the period June to October. The aurrent which passes south of Ceylon merges partly

ISaling Ifrections for the Bay of Bengal. H.0. Pub. No. 64, 4 th Ed. (Washington, D. C.: 1951). 
with the northeast drift near the Andaman Islands and is partly deflected to the south as it approaches the west corner of sumatra. During this period of the year the Southern Monsoon Current together with the Equatorial Counter Current are shown as one broad band of eastward flowing current. Tne Equatorial Counter Current is centered on the Equator or a little south of it and remains there during the entire year as an east set current. Between these two currents there is a zone at about $2^{\circ} \mathrm{N}$ to $5^{\circ} \mathrm{N}$ where the current is not only weaker but is more variable in direction.

In october the southwest monsoon winds are so weak that the Southern Monsoon Current has decayed into a weak eastward drift and the drift current in the central bay takes on a cyclonic circulation. However, the Counter Current becomes essentially stronger during this month. From June to October the greater part of the water mass of the Monsoon Current joins with the water of the Equatorial Counter Current west of Sumatra and turns south in a broad front to pass over into the South Equatorial Current. I

The South Equatorial Current is steady during the entire year and is set toward the west. It extends from the northwest corner of Australia between $20^{\circ} \mathrm{S}$ and $10^{\circ} \mathrm{S}$ to the other side of the ocean as far as Madagascar. There is always a current axis which is readily distinguishable by the higher velocities. In July and August the current axis runs close to the coast of Java, but is deflected southwestward when jolning the water masses of the monsoon current which come from the north along the coast of Sumatra. Most

${ }^{1}$ Klaus Wyrtki, "Physical Ocennography of the Southeast Astan Waters," NAGA Report, II (ta Jolla, California: Scripps Institution of Oceanography, 1961), p. 19. 
of the water in the South Equatorial Current comes from water masses to the south but a considerable part comes from the upwelling region to the northeast of Australia during the late summer and part comes from the Timor Sea.

By December, northeast monsoon conditions are established, and the current system of the northeast Indian Ocean has undergone a complete change. The axis of the South Equatorial Current no longer reaches the coast of Java but has shifted to the south of $10^{\circ} \mathrm{S}$ latitude. This condition allows a strong eastward flowing current to develop off the south coast of Java. This Java Coastal Current reaches its strongest development in February, when it is reinforced by west winds. There also appears to be a temporary weak upwelling along the boundary between the Java Coastal Current and the South Equatorial Current. The Java Coastal Current remains steady until June and, therefore, it is believed that it is caused by the dynamic topography of the sea surface rather than by winds. ${ }^{1}$

In February the South Equatorial Current rises off the west coast of Australia and as it flows toward the north a divergence is caused by a branching off of one part of the current which flows toward the Timor Sea. The main axis of the South Equatorial Current turns west from the northwest corner of Australia and is joined by the water masses of the Counter Current which have been deflected southward around Sumatra. The current charts for the month of August (Fig. 8) and February (Fig. 9) demonstrate the great changes which take place in the circulation of the northeast Indian ocean between the heights of the southwest monsoon and northeast monsoon, respectively. 
During December the North Equatorial Current develops in the southern part of the Bay of Bengal and is present only during the period from December to April. This current rises near the northwest corner of Sumatra and receives part of its water from the Malacca Strait, but is supplied chiefly by water from the Counter Current, which is deflected northward off the west coast of Sumatra. The North Equatorial Current flows toward the west and reaches maximal development during the period January to March. At the same time the axis of the Equatorial Counter Current, which lies near the Equator over most of the year, is shifted southward to about $4^{\circ} \mathrm{S}$ latitute. During January and February when the northeast monsoon is at maximal development a large anticyclonic gyre is formed in the Bay of Bengal. Also south of the axis of the North Equatorial Current a southwest drift caused by the monsoon extends over the Equator to the south. The northeast monsoon ends in March and in April the North Equatorial Current is still present but very weak.

Two extensive regions of upwelling were found in the northeast Indian Ocean according to Rochford ${ }^{2}$ after examination of data from six cruises of the Diamantina completed since 1958. One of the regions lies off the northwest coast of Australia and the other is in the Arafura Sea. The upwelling is especially strong during the summer monsoon season. Within each of these regions the inorganic phosphate content rear the surface was comparatively high, reaching values greater than $0.20 \mu \mathrm{g}$ - atoms/1., and the origin of this

${ }^{I}$ D. J. Rochford, "Hydrology of the Indian Ocean," Australian Journal of Marine and Freshwater Research, XIII, No. 3 (Dec. 1962), pp. $226-251$. 
water rich in phosphate could only be explained through the process of upwelling. Circulation between the Pacific Ocean and Indian Ocean has also been related to the upwelling which occurs in the region of the Arafura Sea. Water which rises toward the surface is replaced at intermediate depths by water from the Banda Sea. In this way the subsurface water of the northeast Indian Ocean between Indonesia and Australia is renewed by water which comes indirectly from the Pacific Ocean by way of the Banda and Arafura Seas. Surface Water Properties. The Bay of Bengal is distinguished by the contrast in properties of the water masses which occupy the surface layer to a depth of 100 to 150 meters. La Fond has divided the surface waters of the western part of the bay into three distinct water masses. I At any particular season these water masses are found at approximately the same locations although they do migrate seasonally in response to the monsoon circulation. The three water masses referred to are the Northern Dilute Water, a transition water, and the Southern Bay of Bengal Water.

The Northern Dilute Water is formed at the head of the bay near the mouths of the large rivers which empty into this area. The Ganges and Brahmaputra Rivers discharge the greatest volume of fresh water with the major dilution taking place in the fall. The Irawaddy, Mahanadi and other rivers add to this volume and bring the estimated discharge of fresh water to $10^{11}$ cubic meters during the fall season. This river water is then mixed by tidal action and currents with the

${ }^{1}$ E. C. La Ford, "On the Circulation of the Surface Layers off the East Coast of India," Anähra University Memoirs in.Oceanography, II (Waltair: Andhra University, 1958), pp. I-ll. 
higher salinity water in the estuaries and over the continental shelf to form the Northern Dilute Water. This water mass is the lowest in density of the three surface water masses with a value of less than 19 in terms of Sigma-t. During October the Northern Dlute Water attains its minimum density and is spread over a large portion of the northwestern bay. Furthermore, the currents set up by the wind system during october are toward the southwest and carry the dilute water along the east coast of India almost to Ceylon. Here the Northern Dilute Water mixes with the Southern Bay of Bengal Water to form the transition water. The transition water with a Sigma-t value between 19 and 21 is spread over the surface of the central part of the bay during the fall season. The Southern Bay of Bengal Water is the major surface water mass of the Bay of Bengal and has a Sigma-t value between 21 and 22 . It is the result of the mixing of Northern Dilute Water with all other surface waters of the Bay of Bengal before it reaches the southern part of the bay. The Southern Bay of Bengal Water is not found along the east coast of India during the fall season and extends across the southern and central part of the bay in an area just south of the transition water.

In March the surface water is largely Southern Bay of Bengal Water. This water is carried north along the east coast of India by the northeast coastal current which is produced by the prevailing wind system in early spring. ${ }^{1}$ The Northern Dilute water is denser during this season and is confined to the northerm part of the bay.

The greatest annual range of temperature in the Bay of Bengal is found in the northern part near Calcutta where the monthly average 
varies by about $6^{\circ} \mathrm{C}$ throughout the year. The annual range decreases from north to south; and at Madras, along the east coast of India, the range of monthly average temperature is about $3^{\circ} \mathrm{C}$. Minimum temperatures occur from December to February, and maximum temperatures are present in September and October in the surface water. Near Calcutta, the average surface temperature decreases to about $23^{\circ} \mathrm{C}$, which is the lowest for the Bay of Bengal in the winter season, and increases to $29^{\circ} \mathrm{C}$ in the summer. The temperature range is not nearly as great here as in the Arabian Sea.

Salinity in the surface layer likewise increases from north to south in the Bay of Bengal, and the annual range of salinity decreases from north to south. These are attributed to the cycles of annual runoff of the major rivers which empty into the head of the bay. Minimum value for salinfty occurs near Calcutta where it arops to a monthly average of less than $20 \%$ in September and October. Salinity In the offshore waters of the Bay of Bengal does not usually exceed $34 \%$

In the region between Java and Australia, the greatest annual variation in surface temperature is found along the northwest coast of Australia. Here the temperature is $29^{\circ} \mathrm{C}$ during the northwest monsoon and decreases to $24^{\circ} \mathrm{C}$ in July and August at the time of the strongest upwelling. ${ }^{I}$ Near the coast of Java, the monthly average varles over the year from $27^{\circ} \mathrm{C}$ in August to $29^{\circ} \mathrm{C}$ in February.

During August when the South Equatorial Current extends all the way to the Java coast, water of high salinity, over $34 \%$, is found to the south of Java. From December to February, the Java Coastal

${ }^{1}$ Wyrtki, NAGA Report, II, p. 33. 
Current is present and carries water of low salinity along the Java coast. The low salinity water originates to the southwest of Sumatra where high rainfall causes a continual decrease of the salinity of the passing water. The lowest values of salinity occur in January at the end of the main rainy season. Near the coast of Australia, the salinity increases to over $35 \%$ and does not vary much throughout the year. The greatest variation in salinity is found near the Java coast in the range of the Java Coastal Current where the annual variation is more than $1.0 \%$

Subsurface Vater. Below the surface waters, the Indian Equatorial Water Mass penetrates 1nto the Bay of Bengal and is present at depths greater than 100 to 150 meters. This water mass is formed as the result of mixing between hlgh-salinity water from the Arabian sea and North Indian ocean deep water. In the central and southern parts of the bay, the Indian Equatorial Water is present to depths of about 1,000 meters. Its temperature decreases with depth from about $15^{\circ} \mathrm{C}$ to $5^{\circ} \mathrm{C}$, and the salinity remains quite constant between 35.0 and $34.1 \%$

In the Indo-Australian Basin, three different water masses have been identifled by Rochford ${ }^{I}$ at intermediate depths. Maxima and minima in the temperature-salinity diagrams, in conjunction with performed phosphate, were used for ldentification of the major paths of spreading. These three water masses which make up the intermediate water of the Indo-Australian Basin are (1) the Antarctic Intermediate Nater, (2) the North-West Indian Intermediate Water, and (3) the Banda Intermediate Water.

ID. J. Rochford, "Hydrology of the Indian Ocean," Australian Joumal of Marine and Freshwater Research, XII (1961), pp. 129-149. 
The Antarctic Intermediate Water approaches the surface in this region and is the uppermost of the three vater masses. It occurs as a salinity minimum within the density range of 27.00 to $28.28 \sigma_{*}$. It has been possible to trace the spread of this water by 1 ts relatively high phosphate content which exceeds $0.9 \mu \mathrm{g}$ - atoms $/ 1$.

The North-West Indian Intermediate Water appears as a salinity maximum Immediately below the Antarctic Intermediate Water and has a density range of 27.20 to $27.50 \sigma_{t}$. The salinity maximum is the result of mixing with high salinity water of Arabian Sea origin. This water spreads eastward at about $20^{\circ} \mathrm{S}$ from its origin in the northwest and gradually loses its high salinity by mixing with the other two intermediate water masses. An oxygen minimum is another feature by which this water mass may be identified in the IndoAustrallan Basin.

The deepest of the three water masses is the Banda Intermediate Water lying within the $\sigma_{t}$ range of 27.28 to 27.59 . This water enters the Indo-Australian Basin from the northeast and is characterized by low salinity and an oxygen maximum. The performed phosphorous distribution shows tongues of low values (less than $0.50 \mu \mathrm{g}$ - atoms/1.) extending westward from the Timor Sea to about $100^{\circ} \mathrm{E}$ and southwestward to about $20^{\circ} \mathrm{S}$.

The Deep Water. At depths greater than about 1,500 meters, the North Indian Deep Water fllls the basins and spreads Into the Bay of Bengal. It is comparatively high in oxygen as a result of the participation of Antarctic Bottom Water in its formation. Arabian Sea Intermediate Water and Indian Ocean Bottom Water also contribute to the formation of this water mass. The salinity maximum which occurs In the upper deep water is attributed to the influence of Arabian 
Sea Intermediate Water. The deep water has a temperature between $1.6^{\circ} \mathrm{C}$ and $2.8^{\circ} \mathrm{C}$, a salinity of $34.68 \%$ to $34.78 \%$, and an oxygen content of 3.18 to $4.17 \mathrm{ml} / 1 .^{1}$

Special conditions exist in the Andaman Sea which are characteristic of all semi-enclosed basins. Water below the sill depth, which is at about 1,500 meters, assumes a constant temperature and salinity which approximates the temperature and salinity at this depth of the water outside the basin. The temperature remains close to $4.8^{\circ} \mathrm{C}$, and the salinity does not vary from about $34.9 \%$ from the sill depth to the bottom.

Temperature-Salinity Diagrams. The four cross-sectional T-S diagrams at the end of this chapter bring out the variability according to geographic location of the water masses beneath the surface layer. These T-S diagrams were not projected all the way to the surface because the surface waters vary so widely with fluctuations in the climate and currents that they are not included in the analysis. The observation symbols on the T-S diagrams correspond to the station symbols on the accompanying charts and tables, for each cross section in the Bay of Bengal and the Indo-Australian Basin. The numbers which appear beside the symbols on the diagrams Indicate the depths of the observations.

It is apparent from the T-S relationship that the subsurface waters of the Bay of Bengal are very uniform in all parts of the bay north of $5^{\circ} \mathrm{N}$ and can be 1dentified as the Indian Equatorial Intermediate Water. This water also crosses the Equator and extends in a southeastwari direction to the southern end of Sumatra. p. 86 .

${ }^{1}$ Muromtsev, Basic Outline of the Hydrology of the Indian Ocean, 
The intermediate depth water between the norichern coast of Australia and the Indonesian Archipelago consists mainly of Banda Intermediate Water, which is formed in this region by inflow and subsequent mixing of water from the Banda Sea. The southernmost station in the section $\mathrm{FF}^{\prime}$ is shown to lie within the T-S envelope of South Indian Central Water. Stations farther to the north show a gradual decrease in salinfty in the direction of Indonesta. The South Indian Central Water spreads eastward along the north coast of Australia to about longltude $123^{\circ} \mathrm{E}$. The Indo-Australian Intermediate Water spreads west in the subsurface layers to about $77^{\circ} \mathrm{E}$ longitude. West of this, the Indian Equatorial Water is present. The deep and bottom waters for the entire region show great uniformity and are identified as Deep and Bottom Waters of the Indian Ocean. 


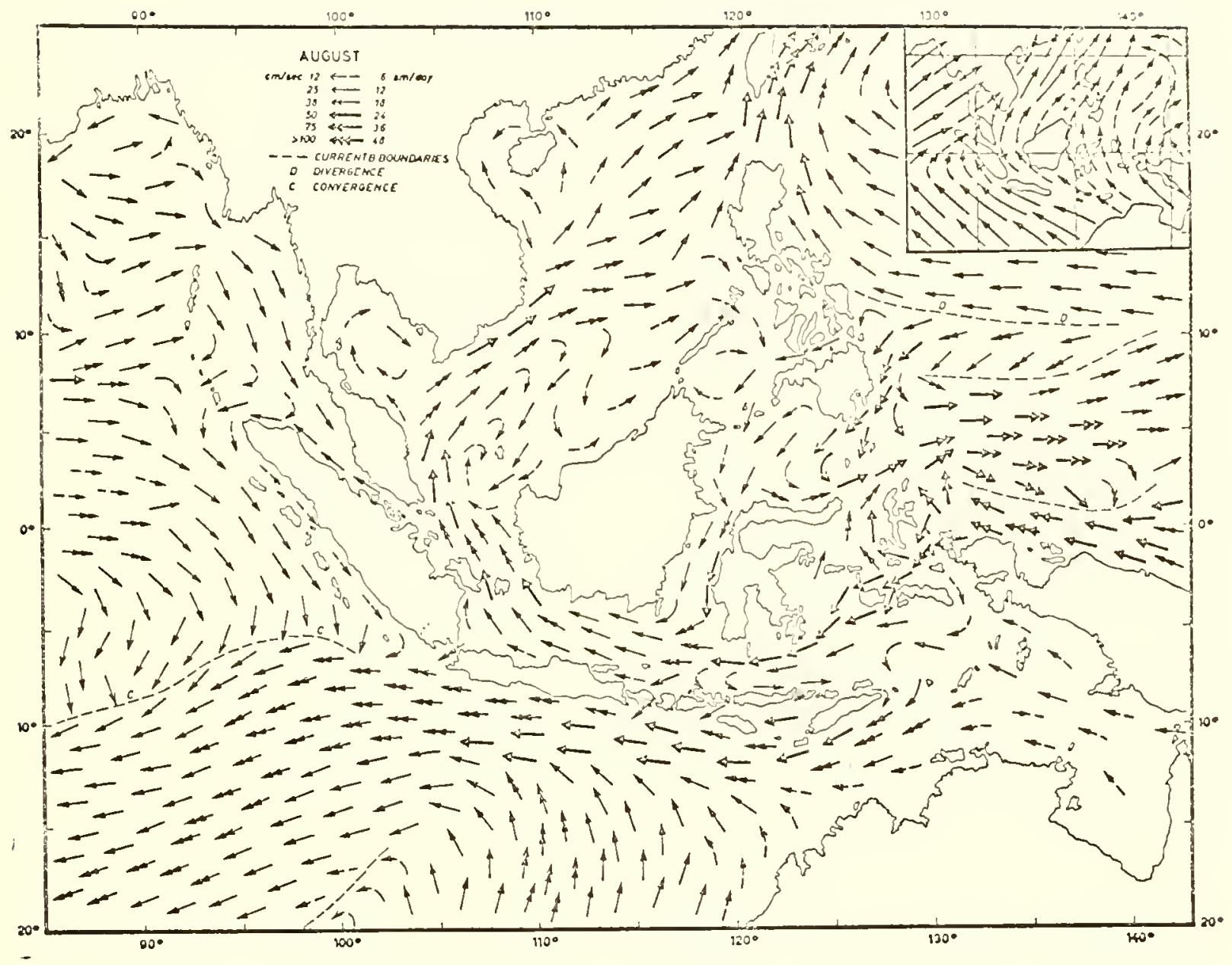

Fig. 8. Surface Currents in August

(from Wyrtk1, NAGA Report, II) 


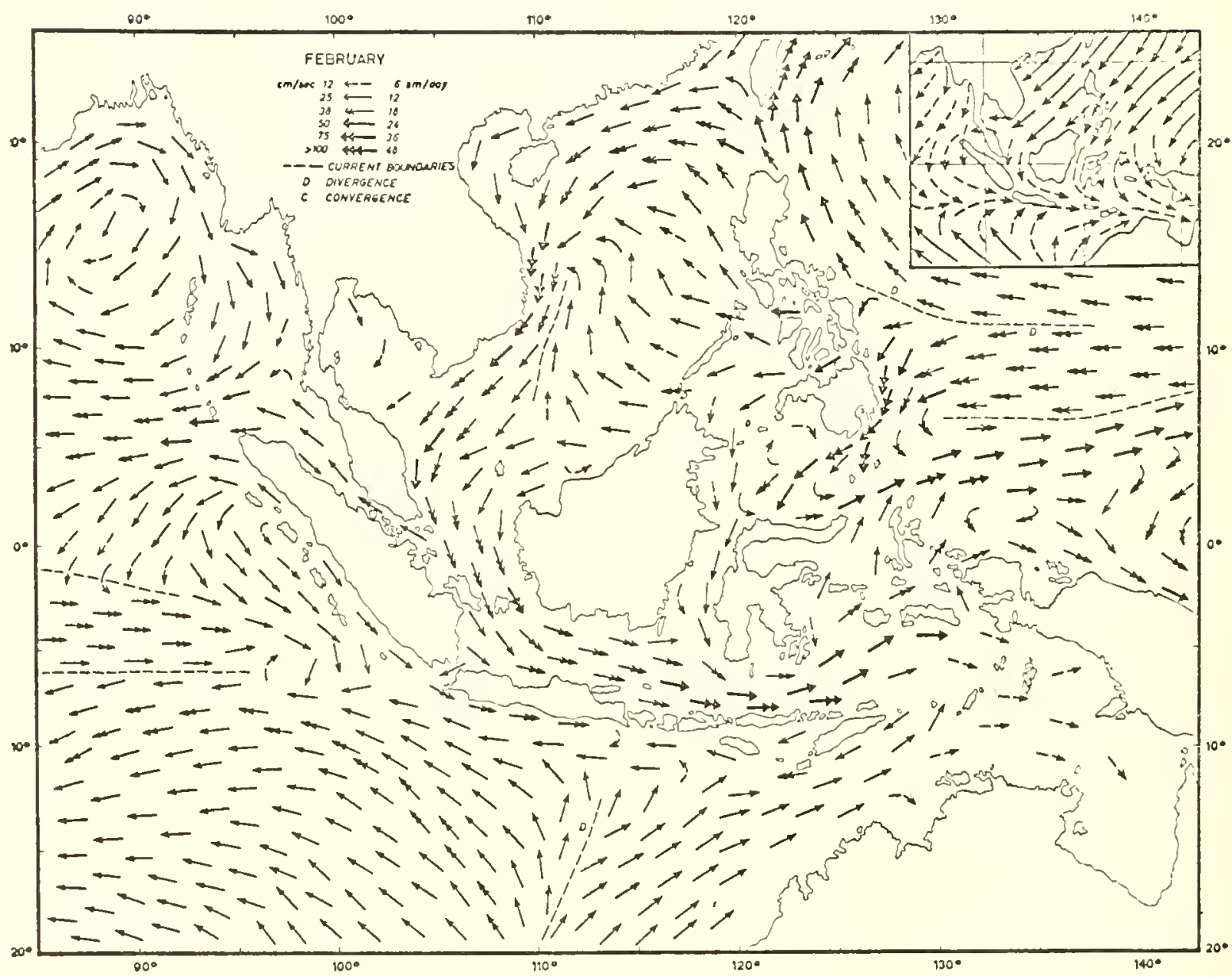

Fig. 9. Surface Currents in February (Prom Wyrtk1, NAGA Report, II) 
BAY OF BENGAT,

NORIH-SOUTH SECIION CC'

\begin{tabular}{|c|c|c|c|c|c|}
\hline Symbol & $\begin{array}{c}\text { NODC } \\
\text { Cruise No. }\end{array}$ & $\begin{array}{c}\text { Consec. } \\
\text { No. } \\
\end{array}$ & Coordinates & ShIp & Year \\
\hline$\bigotimes$ & 90004 & 177 & $\begin{array}{l}20^{\circ} 55^{\prime} \mathrm{N} \\
88^{\circ} \mathrm{O} 1^{\prime} \mathrm{E}\end{array}$ & $\mathrm{OB}$ & 1957 \\
\hline 0 & 90004 & 175 & $\begin{array}{l}16^{\circ} 51^{\prime} \mathrm{N} \\
88^{\circ} 10^{\prime} \mathrm{E}\end{array}$ & $\mathrm{OB}$ & 1957 \\
\hline$\Delta$ & 90004 & 173 & $\begin{array}{l}13^{\circ} 42^{i} \mathrm{~N} \\
88^{\circ} 13^{\prime} \mathrm{E}\end{array}$ & $O B$ & 1957 \\
\hline$\otimes$ & 90004 & 172 & $\begin{array}{l}12^{\circ} 21^{\prime} \mathrm{N} \\
88^{\circ} 09^{\prime} \mathrm{E}\end{array}$ & $O B$ & 1957 \\
\hline$\square$ & 90004 & 170 & $\begin{array}{l}10^{\circ} 06^{\prime} \mathrm{N} \\
88^{\circ} 08^{\prime} \mathrm{E}\end{array}$ & $O B$ & 1957 \\
\hline$\diamond$ & 90004 & 169 & $\begin{array}{l}07^{\circ} 56^{\prime} \mathrm{N} \\
88^{\circ} 03^{\prime} \mathrm{E}\end{array}$ & $O B$ & 1957 \\
\hline$\forall$ & 31090 & 010 & $\begin{array}{l}06^{\circ} 10^{2} \mathrm{~N} \\
86^{\circ} 00^{2} \mathrm{E}\end{array}$ & SERRANO & 1963 \\
\hline$\nabla$ & 31201 & 007 & $\begin{array}{l}04^{\circ} 58^{\prime} \mathrm{N} \\
84^{\circ} 13^{\prime} \mathrm{E}\end{array}$ & PIONEER & 1964 \\
\hline$x$ & 31201 & 009 & $\begin{array}{l}02^{\circ} 53^{\prime} \mathrm{N} \\
84^{\circ} 14^{\prime} \mathrm{E}\end{array}$ & PIONEFR & 1964 \\
\hline
\end{tabular}


TABLE 4.

BAY OF BENGAL

NORTHWEST-SOUTHEAST SECTION DD*

\begin{tabular}{|c|c|c|c|c|c|}
\hline Symbol & $\begin{array}{c}\text { NODC } \\
\text { Cruise No. }\end{array}$ & $\begin{array}{c}\text { Consec. } \\
\text { No. } \\
\end{array}$ & Coordinates & Sh1p & Year \\
\hline$x$ & 31090 & 018 & $\begin{array}{l}15^{\circ} 03^{\prime N} \\
81^{\circ} 02^{\prime} \mathrm{E}\end{array}$ & SERRANO & 1963 \\
\hline 0 & 31090 & 016 & $\begin{array}{l}13^{\circ} 58^{s} \mathrm{~N} \\
80^{\circ} 49^{\circ} \mathrm{E}\end{array}$ & SERRANO & 1963 \\
\hline$\Delta$ & 31090 & 015 & $\begin{array}{l}08^{\circ} 02^{i} \mathrm{~N} \\
81^{\circ} 59^{\prime} \mathrm{E}\end{array}$ & SERRANO & 1963 \\
\hline$\forall$ & 31090 & 010 & $\begin{array}{l}06^{\circ} 10^{\prime} \mathrm{N} \\
86^{\circ} 00^{\prime} \mathrm{E}\end{array}$ & SERRANO & 1963 \\
\hline$\square$ & 31184 & 104 & $\begin{array}{l}05^{\circ} 00^{\prime} \mathrm{N} \\
89^{\circ} \mathrm{O} 1^{\prime} \mathrm{E}\end{array}$ & ARGO & 1962 \\
\hline$\otimes$ & 31201 & 044 & $\begin{array}{l}02^{\circ} 15^{\prime} \mathrm{N} \\
92^{\circ} \mathrm{O} 1^{\prime} \mathrm{E}\end{array}$ & PIONEER & 1964 \\
\hline$\diamond$ & 09029 & 030 & $\begin{array}{l}00^{\circ} 00^{\prime} \mathrm{N} \\
95^{\circ} 00^{\prime} \mathrm{E}\end{array}$ & DIAMANTINA & 1962 \\
\hline$\nabla$ & 26009 & 218 & $\begin{array}{l}03^{\circ} 03^{\prime} \mathrm{S} \\
98^{\circ} 13^{\prime} \mathrm{E}\end{array}$ & DANA & 1929 \\
\hline$\square$ & 90010 & 035 & $\begin{array}{l}05^{\circ} 09^{\prime} \mathrm{S} \\
99^{\circ} 52^{\prime} \mathrm{E}\end{array}$ & VITYAZ & 1959 \\
\hline 8 & 90033 & 020 & $\begin{array}{r}07^{\circ} 22^{\prime} \mathrm{S} \\
102^{\circ} 40^{\prime} \mathrm{E}\end{array}$ & NEVELSKOI & 1962 \\
\hline
\end{tabular}


TABIE 5.

INDO-AUSTRALIAN BASIN

EAST-WEST SECIION EE'

\begin{tabular}{|c|c|c|c|c|c|}
\hline Symbol & $\begin{array}{c}\text { NODC } \\
\text { Cruise No. } \\
\end{array}$ & $\begin{array}{c}\text { Consec. } \\
\text { No. } \\
\end{array}$ & Coordinates & Ship & Year \\
\hline$x$ & 90010 & 133 & $\begin{array}{l}08^{\circ} 59^{\prime} \mathrm{S} \\
67^{\circ} 55^{\prime} \mathrm{E}\end{array}$ & VITYAZ & 1960 \\
\hline $\mathrm{O}$ & 90034 & 089 & $\begin{array}{l}08^{\circ} 05^{\prime} \mathrm{S} \\
77^{\circ} 05^{\prime} \mathrm{E}\end{array}$ & VITYAZ & 1962 \\
\hline$\triangle$ & 90010 & 084 & $\begin{array}{l}09^{\circ} 56^{\prime} \mathrm{S} \\
86^{\circ} 27^{\prime} \mathrm{E}\end{array}$ & VITYAZ & 1960 \\
\hline$\square$ & 26009 & 208 & $\begin{array}{l}12^{\circ} 05^{\prime} \mathrm{S} \\
96^{\circ} 45^{\prime} \mathrm{E}\end{array}$ & DANA & 1929 \\
\hline$\otimes$ & 90010 & 042 & $\begin{array}{r}15^{\circ} 53^{\circ} \mathrm{S} \\
102^{\circ} \mathrm{c}^{\circ} \mathrm{E}\end{array}$ & VITYAZ, & 1959 \\
\hline$\diamond$ & 90034 & 005 & $\begin{array}{r}12^{\circ} 00^{\prime} \mathrm{S} \\
105^{\circ} 16^{\circ} \mathrm{E}\end{array}$ & VITYAZ & 1962 \\
\hline$\forall$ & 09030 & 033 & $\begin{array}{r}08^{\circ} 53^{\prime} \mathrm{S} \\
108^{\circ} 12^{\prime} \mathrm{E}\end{array}$ & DIAMANTINA & 1962 \\
\hline
\end{tabular}


TABLE 6.

$$
\begin{aligned}
& \text { INDO-AUSTRATIAN BASIN } \\
& \text { NORTH-SOUTH SECTION FF' }
\end{aligned}
$$

\begin{tabular}{|c|c|c|c|c|c|}
\hline Symbol & $\begin{array}{c}\text { NODC } \\
\text { Cruise No. }\end{array}$ & $\begin{array}{c}\text { Consec. } \\
\text { No. } \\
\end{array}$ & Coordinates & Shlp & Year \\
\hline$x$ & 90010 & OII & $\begin{array}{r}09^{\circ} 38^{\circ} \mathrm{S} \\
115^{\circ} 05^{\prime} \mathrm{E}\end{array}$ & VITYYAZ & 1959 \\
\hline $\mathrm{O}$ & 09009 & 024 & $\begin{array}{r}14^{\circ} 07^{\prime} \mathrm{S} \\
115^{\circ} 23^{\prime} \mathrm{E}\end{array}$ & DIAMANTINA & 1961 \\
\hline$\triangle$ & 09009 & 006 & $\begin{array}{r}14^{\circ} 33^{\prime} \mathrm{S} \\
119^{\circ} 50^{\circ} \mathrm{E}\end{array}$ & DIAMANTINA & 1961 \\
\hline$\square$ & 09001 & 008 & $\begin{array}{r}17^{\circ} 22^{\prime} \mathrm{S} \\
118^{\circ} 16^{\prime} \mathrm{E}\end{array}$ & DIAMAN'INA & 1959 \\
\hline$\diamond$ & 09030 & 039 & $\begin{array}{l}19^{\circ} 11^{\prime S} \mathrm{~S} \\
113^{\circ} 34^{\circ} \mathrm{E}\end{array}$ & DIAMANTINA & $196 ?$ \\
\hline$\otimes$ & 09001 & 007 & $\begin{array}{r}22^{\circ} 59^{\prime} \mathrm{S} \\
111^{\circ} 42^{\prime} \mathrm{E}\end{array}$ & DIAMANTINA & 1959 \\
\hline
\end{tabular}




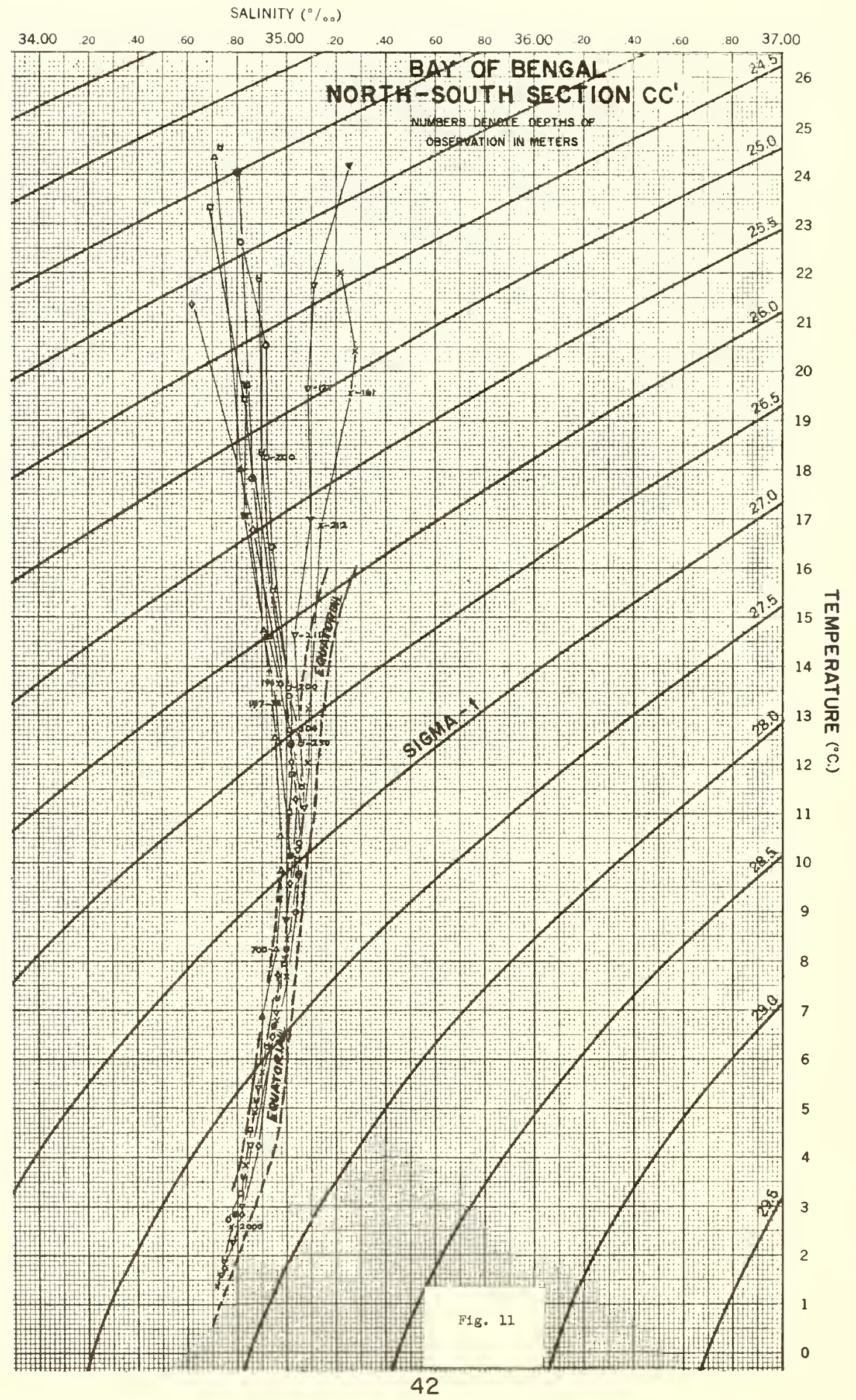




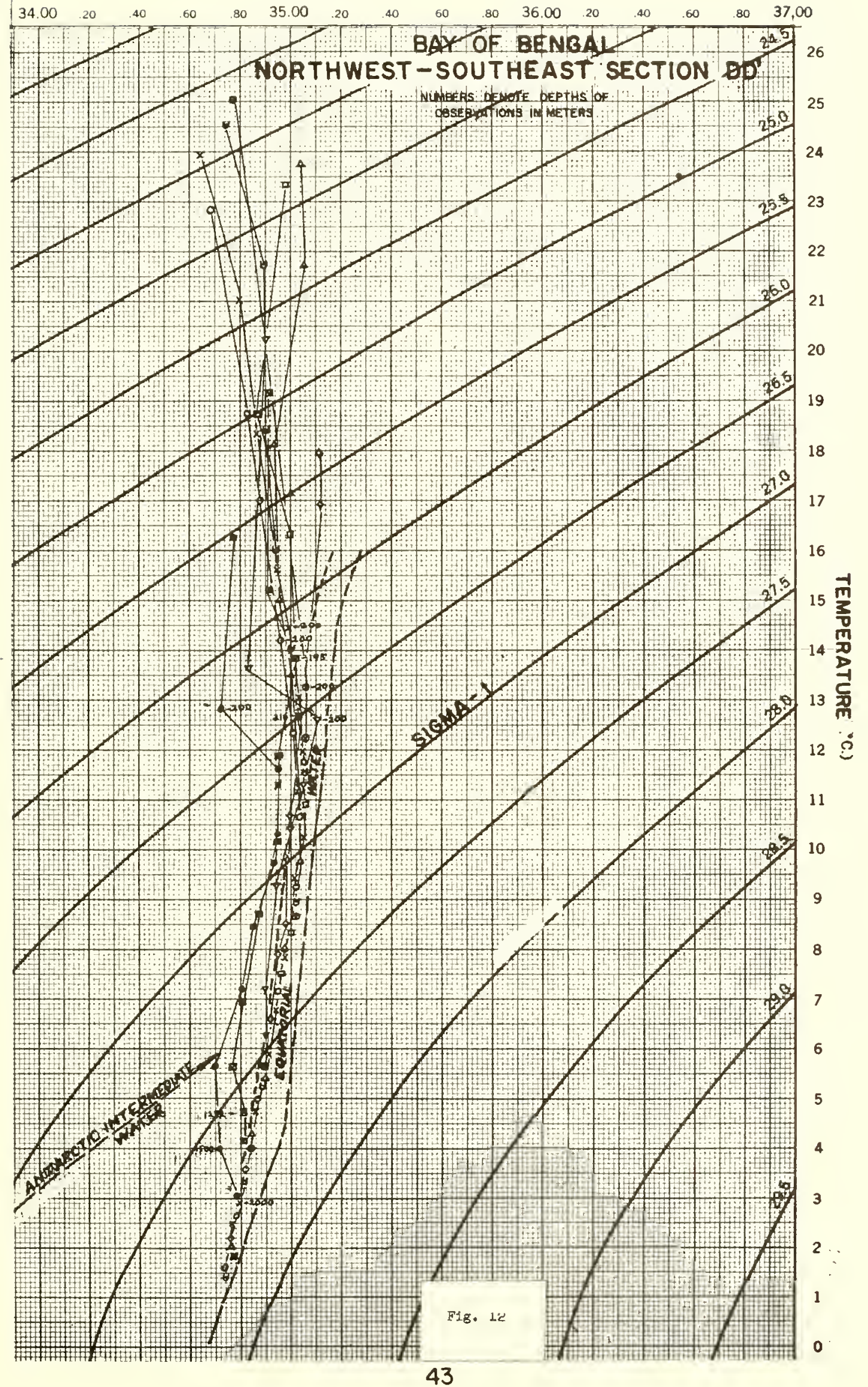




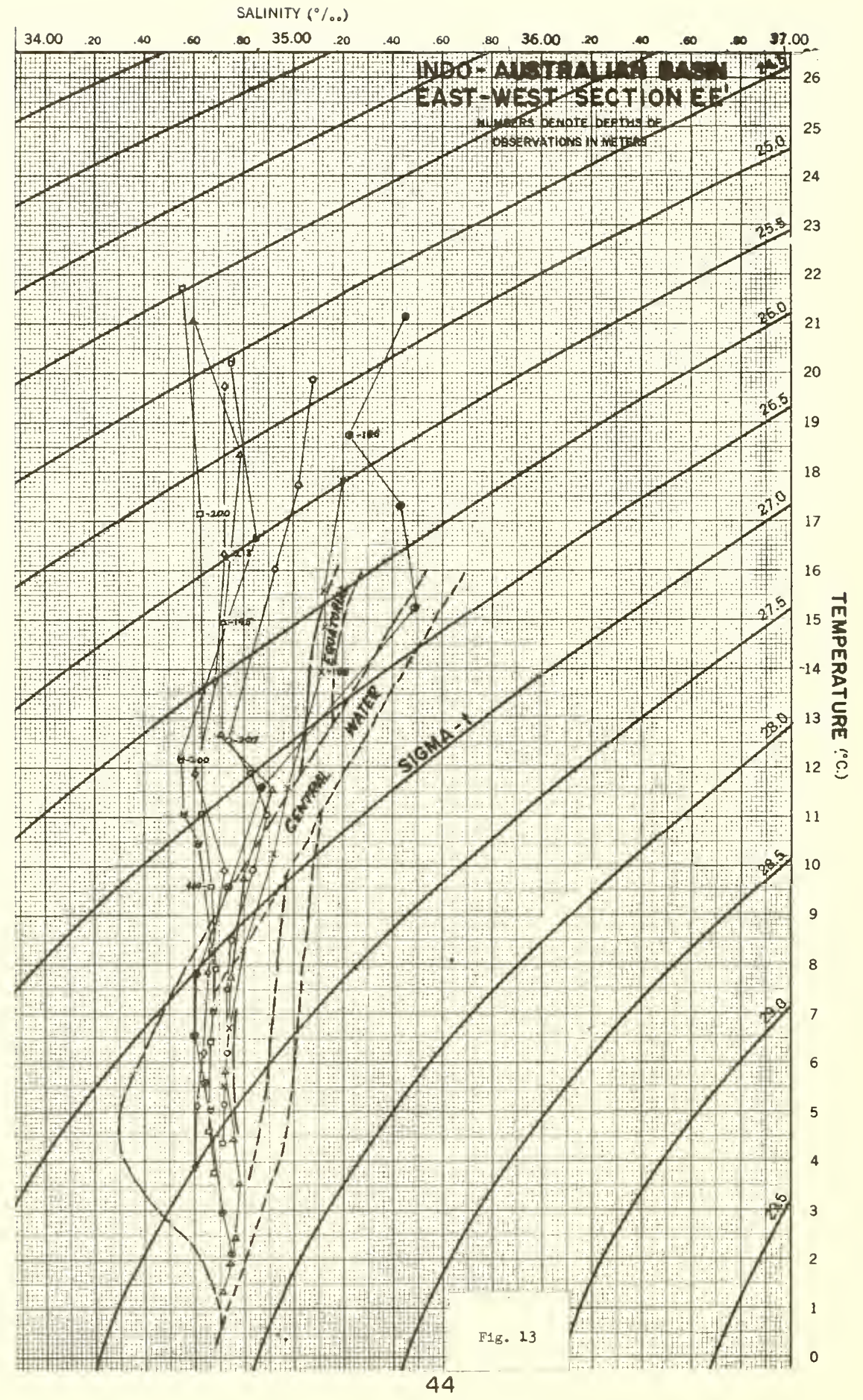




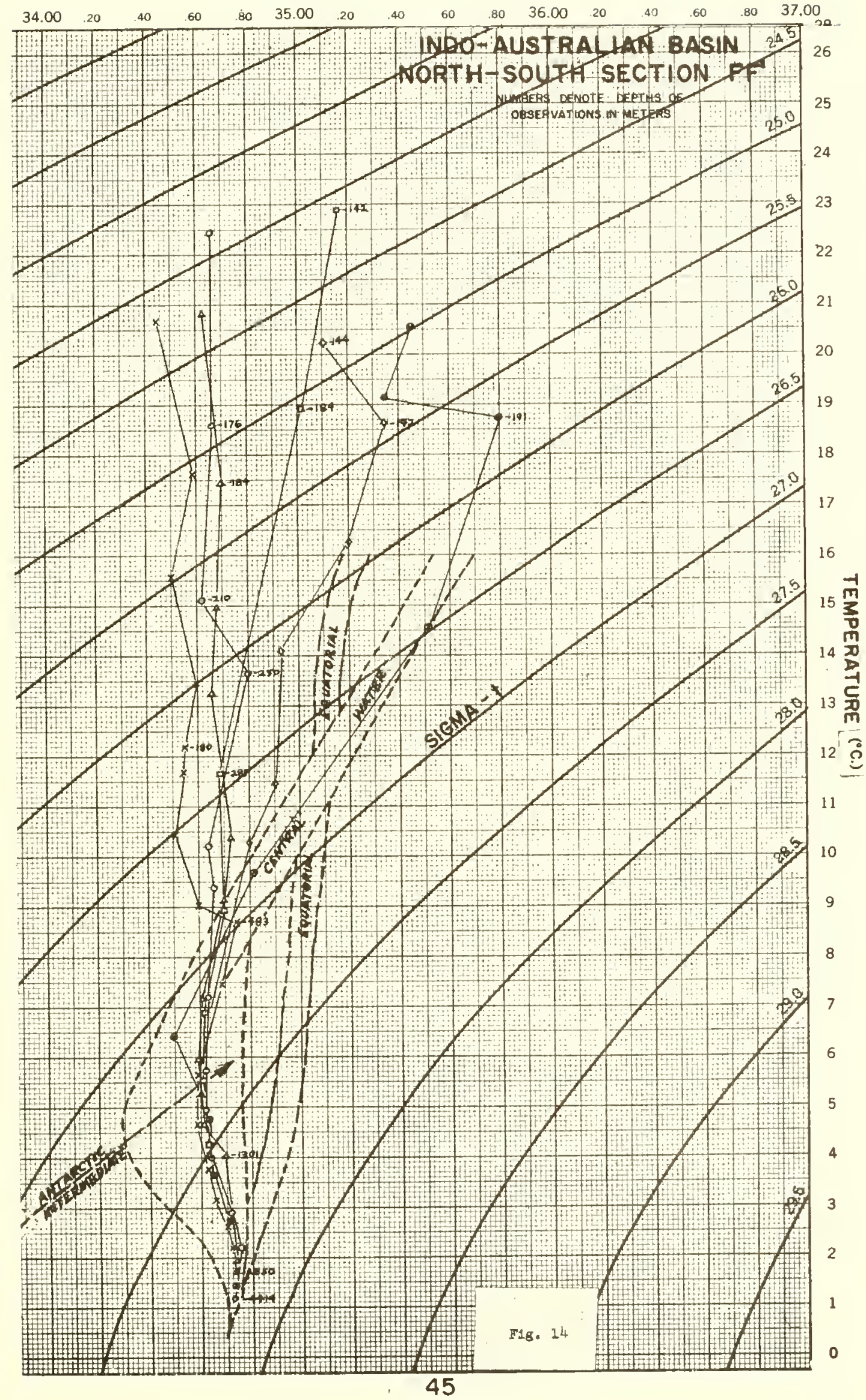




\section{CENTRAL AND SOUTHERN INDIAN OCEAN}

The central and southern parts of the Indian Ocean Include the regions which are least affected by the monsoon forces which play such an important role in the circulation and water mass structure in the northern part of the ocean. The water masses in these parts are only indirectly influenced by the marginal seas of the northern Indian Ocean and they are analogous in formation to similar water masses in the Atlantic and Pacific Oceans.

Circulation. The absence of a sufficient number of direct current measurements in the Indian ocean has resulted in the study of currents by indirect methods. One of these is the dynamic method which Is very exacting in its requirements. The measurements must be simultaneous and recurrent, and should be arranged with respect to any currents which may exist. This method has been used extensively in the southeast part of the ocean near Australia and also in the southwest off the coasts of Africa and Madagascar.

Another indirect method is the qualitative method, which is less exacting, and is based on the property of ocean water to maintain its characteristics for a lung period of time as it spreads in the direction of flow from the region where it is formed. Temperature, salinity, and sometimes oxygen content, are the indices which are usually selected to trace the water movements. Up to the present time, the qualitative method has been useful to furnish a first approximition of the general circulation of the water masses In the Indian Cosin. 1

$$
\text { p. } 96 .
$$

${ }^{I}$ Muromtsev, Basic OutIIne of the Hydrology of the Indian Ocean, 
The surface circulation in the southern Indian Ocean is similar to the circulation in the southern Atlantic and southern Pacific oceans. It consists of a counter-clockwise gyre which occupies the central part of the ocean between Australfa and Madagascar and is bounded on the soutin by the West Wind Drift. The northern part of the gyre is formed by the westward flowtng South Equatorial Current which extends across the ocean between $20^{\circ} \mathrm{S}$ and $6^{\circ} \mathrm{S}$. The speed of this current varies in response to the strength of the South-East Trade Winds but continues to the west throughout the year. When this current reaches the shore of Africa it supplies both the Equatorial Counter current to the north and the Agulhas Current which flows south between the coist of Afrlca and Madagascar. The Agulhas Current is confined to about 100 kilometers in width and when it reaches the southern tip of Africa, part of the current turns east into the West Wind Drift of the Circumpolar Current and part turns into the Atlantic to form the Benguela Current. During the southwest monsoon the branch of the South Equatorial Current which turns north at the coast of Africa forms the poweriul stream of the Somali Current. This current is set north along the east coast of Africa and continues into the Arabian Sea. It is remarkable for its high velocity of about $200 \mathrm{~cm} / \mathrm{sec}$. Which is comparable to the speed of the Florida Current. ${ }^{1}$

The counter-clockwise gyre is completed on the eastern side of the ocean by a current which flows northward along the west coast of Australia. This current receives its supply from a part of the West Wind Drift which is deilected northward and from water which flows along the south coast of Australla.

${ }^{1}$ George I. PIckard, Descriptive Phys lcal oceanography (The Mackilian Compary, New York, 1903), pp. I3-1i5. 
In the layers of water below the surface layer, the influence of the wind is felt only indirectly in the form of lowering the surface waters, which leads to the development of compensating currents at great depths. The principal agent in determining circulation of the subsurface water is the differences in water densities in varlous parts of the ocean.

The water which sinks at the subtropical convergence located at about $40^{\circ} \mathrm{S}$ latitude forms the Indian Ocean Central Water and as it moves to the north is deflected into an anticyclonic gyre whose center is located southeast of Madagascar. When this water meets the underwater slopes of Madagascar and Africa it turns to the south and returns to the region where it sank. Here 1 it is renewed by further sinking along the subtropical convergence to a depth of about 600 meters in the western part of the ocean. It then bends to the east and completes the anticyclonic gyre. ${ }^{2}$

The deep circulation of the Indian Ocean is divided into two parts by the Central Indian Ridge at a depth of 3,500 meters. The North Indian Deep Water flows south on both sides of the ridge. On the western side the Atlantic Deep Water which flows around the southern tip of Africa plays a part in the circulation and mixes with the North Indian Deep Water. The spread of Atlantic Deep Water In the Indian Ocean is limited by the Agulhas Basin and the Madagascar Basin. When this water flows out of these basins it joins the common deep stream toward the east and southeast and loses its identifying properties. South of $30^{\circ} \mathrm{S}$ latitude the water density in the Indian Ocean is greater than in the Pacific at all depths and as

\footnotetext{
${ }^{2}$ Muromtsev, Ibid, p. 100.
} 
a result there is a unilateral flow of water Irom the Indian Ocean to the Pacific Ocean. Moreover, on the Atlantic side there is a constant inflow of water into the Indian Ocean where it is rapidy transformed.

Antarctic Bottom Water enters the Indian ocean at about $50^{\circ} \mathrm{S}$ latitude and proceeds northward on the east and west sides of the Central Indian Ridge. At approximately $10^{\circ} \mathrm{S}$ latitude the bottom water rises to upper levels and is mixed considerably with the deep waters which are sinking here and its main mass returns to the south in a deep stream. A smaller part of the bottom water flows north Into the Bay of Bengal and the Arabian Sea after having been considerably transformed. Here 1t rises to shoaler depths and returns south in the intermediate current.

A study of the southwest Indian Ocean by Le PIchon Includes an area between $20^{\circ}$ and $70^{\circ} \mathrm{E}$ longitude and $20^{\circ}$ and $50^{\circ} \mathrm{S}$ latitude. This region is bounded on the south by the Antarctic convergence. It was found that below 2,000 meters the whole deep water circulation Is influenced by the inflow of Atlantic Deep Water. Above 2,000 meters water of North Indian origin is fed by the Agulhas Current through the Mozambique Channel. These two inflows with possible adition of North Indian Ocean Deep Water contribute to the formation of a homogeneous water mass which occuples the depths of the Madagascar Bas1n. The bottom topography plays a very important role In this area because the Agulhas Current and its return current are deep currents. Antarctic Bottom Water enters the basin situated between Africa and the Madagascar Ridge. Antarctic Bottom Water

${ }^{1}$ Xavier Le Pichon, "The Deep Water Circulation in the Southwest Indian Ocean," Journal of Geophysical Research (Dec. 1960), pp. 40614074. 
(isotherm $0.25^{\circ} \mathrm{C}$, isohaline $34.70 \%$ ) also enters the Kerguelen

Basin and continues on into the Madagascar Basin. The Mid-oceanic Ridge runs in a southwest to northeast direction and has the effect of separating the bottom topography into three independent basins: the Agulhas Basin, the Kerguelen Basin, and the Madagascar Basin. The Arabian Sea Water is still detected as far south as $40^{\circ} \mathrm{S}$ latitude and is identified as poorly oxygenated water which spreads above the Atlantic Deep Water. South of the Mozambique Channel, however, the Arabian sea Water has lost most of its characteristics and the deep water is more likely a mixture of Antarctic Intermediate Water with Arabian Sea Water, which takes place at the barrier in the Mozambique Channel. The deep water thus formed would flow southward.

The "core" method can be used to trace the Atlantic water into the south Indian ocean. This consists of following the current propagation as indicated by the shape of the isohalines in the layer of maximum salinity. The role of Atlantic Deep Water is important in the formation of South Indian Ocean Deep Water. East of $60^{\circ} \mathrm{E}$ Antarctic Intermediate and Deep Water mix with Atlantic and water of the North Indian Ocean origin to form the South Indian Ocean Deep Water. The influence of the Antarctic waters is probably predominant in this area, but the salinity is maintained by the North Indian Ocean water. After the Atlantic water rounds the southern tip of Afric?, the main flow is directed eastward by the Agulhas Plateau. It then crosses the Mid-Oceanic Ridge and is directed south by the Kerguelen Ridge. Toward the north, the Atlantic water can be traced to $20^{\circ} \mathrm{S}$, where the maximum of salinity disappears. This deep current probably cannot pass through the Mozambique Channel 
and has to return south along the Madagascar Ridge. It has the characteristics of a western boundary current which is deflected away from the continental slope by the bottom topography.

The oxygen content in the salinity maximum is also used to confirm the flow of the Atlantic water. To the south of the Mid-Oceanic Ridge the Atlantic water is important, whereas to the north of the ridge water of North Indian Ocean origin is predominant as shown by comparative oxygen values. Noxth of the ridge the oxygen content in the salinity maximum was 3.57 to $3.68 \mathrm{ml} / \mathrm{l}$., while to the south of the ridge it was $3.99 \mathrm{ml} / \mathrm{I}^{1}$

It appeaxs that the northward flow of Atlantic deep water in the Agulhas Basin is strengthened by a similar flow of Antarctic Bottom Water because the oxygen content increases toward the north While the salinity and temperature decrease. This is probably due to vertical mixing between the two water masses.

Data from three cruises of the Australlan research vessel Diamantina were used by Wyrtk $^{2}$ to calculate geopotential anomalies and circulation in the southeast Indian Ocean. A constant depth of 1,750 meters was selected as a reference level or surface of no motion. A strong current to the south was observed along the coast of Australia as the result of a cyclonic eddy to the west of Perth. This eddy is centered at $32^{\circ} \mathrm{S}, 110^{\circ} \mathrm{E}$ and is remarkably weIl developed even at the 400 decibar Ievel.

\section{Ibid.}

$2_{K}$. Wyrtki, "Geopotential Topographies and Associated Circulation in the South-Eastern Indian Jesan," Australian Journal of Marine and Freshwater Research, XIII (June 1952), pp. I-17. 
Surface Water Properties. The Fquatorial Surface Water is Iocated between $1-2$ and $6-8^{\circ} \mathrm{S}$ latitude in the Indian Ocean and Inciudes a layer to about 60 meters depth. Its temperature ranges between 26 and $27^{\circ} \mathrm{C}$. The amount of precipitation exceeds evaporation over the entire region, which leads to a freshening of the surface water. Salinity is $34.0-35.0 \%$ with the maximum value in the west and the oxygen content is $3.40-7.46 \mathrm{ml} / 1 .^{1}$

South Tropical Surface Water is formed in the Tradewind Zone, between $6-8$ and $18-23^{\circ} \mathrm{S}$ latitude and occupies the layer to about 150 meters. The constancy of the winds in these latitudes maintains a relatively constant air temperature which is about $1^{\circ}$ cooler than the water temperature. In winter the temperature range in a south to north direction is between 20 and $26^{\circ} \mathrm{C}$ and in summer it is between 25 and $28^{\circ} \mathrm{C}$. Precipitation exceeds evaporation over most of the region and the salinity is $34.5-35.2 \%$ The absolute oxygen content is $3.64-4.83 \mathrm{ml} / \mathrm{l}$.

South Australian Surface Water is present on the eastern side of the ocean between 23 and $35^{\circ} \mathrm{S}$ latitude to a depth of 150 meters. The prevalence of winds from a southern direction and the relatively cold underlying surface of the region result in air temperatures which remain for the greater part of the year 1 to $2^{\circ}$ lower than the water temperatures. The water temperature varies from north to south between $20^{\circ}$ and $15^{\circ} \mathrm{C}$ in the winter time and between $24^{\circ}$ and $19^{\circ} \mathrm{C}$ in the summer. The amount of precipitation is small in this region compared to the evaporation, which determines the significant increase in the salinity of the water, which is 35.0 to $35.8 \%$. The oxygen content is 3.64 to $4.83 \mathrm{ml} / 1$. 
South Central Surface Water is located on the western side of the ocean between $23^{\circ}$ and $40^{\circ} \mathrm{S}$ latitude and is under the influence of wind from the northeast which is 1 to $3^{\circ}$ cooler than the water. The water temperature varies between $26^{\circ}$ and $20^{\circ} \mathrm{C}$ in a north to south direction in February and between $21^{\circ}$ and $15^{\circ} \mathrm{C}$ in August. The degree of evaporation in this region markedly exceeds the precipitation wich leads to a considerable increase in salinity. The salinity is 35.0 to $36.5 \%$ and the dissolved oxygen is 4.27 to 4.93 $\mathrm{ml} / 1$.

South Temperate Surface Water is found between 40 and $50^{\circ} \mathrm{S}$ latitude in the westem part of the ocean and between 35 and $55^{\circ} \mathrm{S}$ latitude in the eastern part. It comes into the Indian Ocean from the Atlantic in the stream of the West Wind Drift. Cyclonic atmospheric condtions in this zone lead to increased preclpitation which results in a marked freshening of the surface water. The air temperature, except in the northern part, remains bigher than the water temperature over the greater part of the year. The temperature in the layer to 200 meters varies between $15^{\circ}$ in the north to $5^{\circ} \mathrm{C}$ in the south in August and between 20 and $7^{\circ} \mathrm{C}$ in February. The salinity decreases from 35.0\% to $33.8 \%$ from north to south and the oxygen content increases from 6.22 to $8.30 \mathrm{ml} / 1$. Subsurface Water. Inmediately below the surface waters there is a layer called the subsurface water which extends to about 500 meters over most of the ocean and in individual regions (western subtropical part) it reaches 600 - 700 meters.

The subsurface water of the southern Indian Ocean is called Indian ocean Central water. This water is believed to be formed by 
the sinking of surface water at the Subtropical Convergence. The southern limit of the Indian Ocean Central Water is located at this convergence, south of which the Central Water is not present. In the region of the convergence the surface salinity and temperature vary rapidly with latitude and the horizontal T-S relation at the surface agrees very well with the vertical T-S relation within the Central Water mass during certain seasons. ${ }^{2}$ A remarkable feature of this water mass is that nearly all temperature and salinity observations fall on a straight line between the points $T=8^{\circ}$, $S=34.60 \%$, and $T=15^{\circ}, S=35.50 \%$ Indian Ocean Central Water extends over the entire width of the southern part of the ocean and spreads north from the Subtroplcal Convergence which is located at $35-40^{\circ} \mathrm{S}$ latitude. It is bounded on the north by a zone of upwelling of intermediate water at $12^{\circ} \mathrm{S}$ latitude. Temperature values range from 8 to $19^{\circ} \mathrm{C}$, salinity is 34.60 to over $36.0 \%$, and the absolute oxygen content is 0.21 to $2.09 \mathrm{mI} / 1$.

Intermediate Water. In view of the fact that the process of formation of intermediate waters involves the mixing of denser water than in the formation of subsurface waters, the former occupy great depths and underlie the subsurface waters. Two intermediate depth waters are found in the southern Indian Ocean, the Antarctic Intermediate Water and the Equatorial Intermediate Water.

The Antarctic Intermediate Water is formed in the Antarctic Convergence at about $50^{\circ} \mathrm{S}$ latitude, where there is sinking of surface water of the Antarctic region. This low temperature water has sufficient density to sink to a depth of 1,000 to 1,600 meters. As

${ }^{1}$ H. V. Sverdrup, Martin W. Johnson, and Richard H. Fleming, The. Oceans (Prentice-HaII, Inc., Fnglewood Cliffs, N. J., 1942), p. 69I. 
the Antarctic Intermediate Water moves north toward the Equator, it gradually tapers out and part of it rises to the surface layer in the south tropical latitudes. Another part crosses the Equator and mixes with Arabian Sea Intermediate Water and bottom water to form deep water. The temperature in the Antarctic Intermediate Water is 3 to $9^{\circ} \mathrm{C}$, salinity is 34.2 to $34.8 \%$ and the oxygen content is 1.41 to $4.40 \mathrm{ml} / \mathrm{l}$.

The Equatorial Intermediate Water which spreads south on the western side of the Indian Ocean is referred to by Sverdrup as Red Sea Water. ${ }^{1}$ This water is formed in the Equatorial region by mixing of Antarctic Intermedite Water and Arabian Sea water which contain a high percentage of water from the Red Sea. As this intermediate water flows south along the coast of Africa its salinity decreases from 35.1\% near the Equator to $34.8 \%$ in the Mozambique Channel. Its temperature varies between 4 and $10^{\circ} \mathrm{C}$ and the oxygen content increases from $0.8 \mathrm{ml} / 1$. near the Equator to $2.0 \mathrm{ml} / 1$. at $20^{\circ} \mathrm{S} 1$ at1tude.

Deep Water. Beneath the intermediate waters the deep water occupies a layer to a depth of 3,500 meters.

North Indian Deep Water is the principal deep water of the Indian ocean. It derives 1 ts name from the fact that it is formed In the northern part of the ocean as a result of deep mixing of three types of water: (I) intermediate water of the Arabian Sea which is warm and saline but low in oxygen, (2) Antarctic Intermediate Water which is relatively cold, fresh and also weak in oxygen, and (3) bottom water which is cold, and relatively rich in salts and 
oxygen. North Indian Deep Water covers the entire expanse of the Indian Ocean and extends into the Arabian Sea and the Bay of Bengal. In the southern part of the ocean, it rises toward the surface north of $50^{\circ} \mathrm{S}$ latitude and a large part of it goes out into the Pacific Ocean south of Australia. It has a temperature of 1.6 to $2.8^{\circ} \mathrm{C}$, salinity is 34.68 to $34.78 \%$, and the absolute oxygen content is 3.18 to $4.17 \mathrm{ml} / 1.1$

Atlantic Deep Water also enters the Indian Ocean south of Africa $^{2}$ and can be traced into the Madagascar Basin. It enters as an eastward directed current below the North Indian Deep Water with which it mixes to form the deep water of the Madagascar Basin. The Atlantic Deep Water is characterized by a high salinity of 34.80 to $34.84 \%$ Its temperature is 2.0 to $2.8^{\circ} \mathrm{C}$ and the oxygen content is 3.92 to $4.60 \mathrm{ml} / \mathrm{l}$.

Bottom Water. The greatest depths of the ocean are occupied by bottom water which lies between the deep water and the bottom. Bottom waters are divided into two types: Antarctic Bottom Water and Indian Ocean Bottom Water.

Antarctic Bottom Water is formed by sinking along the continental slope of Antarctica and mixing with deep water. It is characterIzed by negative temperatures, from -0.24 to $-0.07^{\circ} \mathrm{C}$, and a salinity of 34.67 to $34.69 \%$ The absolute oxygen content is 4.70 to 5.27 $\mathrm{ml} / 1$.

${ }^{1}$ Muromtsev, p. 86.

${ }^{2}$ M. J. Orren, "Hydrological Observations in the South west Indian Ocean," Collected Reprints of the International Indian Ocean Expedition (Bruges: St. Augustin Press, 1965), p. 288. 
Indian Ocean Bottom Water is formed as the result of mixing of Antarctic Bottom Water with North Indian Deep Water as the former flows north on both sides of the Mid-Oceanic Ridge. As a result, the Indian Ocean Bottom Water has higher temperature and higher salinity than Antarctic Bottom Water. It extends into the southern, deepest parts of the Arabian Sea and Into the Bay of Bengal where It rises to higher levels. The temperature ranges from 0.2 to $1.47^{\circ} \mathrm{C}$ and the salinity varles from 34.69 to $34.77 \%$. The oxygen content is 4.03 to $4.68 \mathrm{ml} / \mathrm{l}$.

Temperature-Salinity Diagrams. The three cross-sectional T-S diagrams at the end of this chapter contain stations which are intended to show the transition of water masses in the southern part of the ocean (1) along the east coast of Africa, (2) in the central part of the ocean along a north-south line, and (3) in the eastern part of the ocean. The water mass envelopes which are superimposed on the diagrams as dashed Iines define the principal water masses of the Indian Ocean according to Sverdrup. ${ }^{1}$ The station plots are not extended all the way to the surface and only those observations at depths greater than 150 meters are considered in determining the permanent features in the subsurface water.

The western section $\mathrm{GG}^{\text {: }}$ illustrates the variability of the water along the African coast from the Equatorial region to the southern tip of Africa. Station locations with the corresponding symbols are given in Table 7 and the chart (Fig. 16). The northernmost station located in the Somali Basin shows the strongest influence of Arabian sea water with a salinity maximum at 790 meters. The next station toward the south appears to lie for the most part 
within the envelope of the Equatorial Water Mass and is much less influenced by Arabian Sea water although it st1ll shows up as a salinity maximum. The third station in a north-south direction is located in a transition area where Indian Central Water is present above the Equatorial water. The next three stations farther south are located within the Central Water Mass; however, these stations also present a salinity maximum where Arabian Sea Water comes in at greater depths. The four southernmost stations are located south of the Mozambique Channel and Arablan Sea Water appears only as a slight salinity maximum at about 1,500 meters on all but the southernmost station. The deep water at these four stations also shows a salinity maximum in the deep water greater than $34.80 \%$, which is caused by the influx of Atlantic Deep Water.

The central section $\mathrm{HH}^{\prime}$ is taken in a north-south direction through the central part of the Indian ocean and the station locations are given in Table 8. The northernmost station is located within the Equatorial Water Mass and all other stations except the two southernmost stations are within the Indian Ocean Central Water. The two southernmost stations are located south of $45^{\circ} \mathrm{S}$ latitude and therefore are south of the Subtropical Convergence. The Indian Ocean Central Water is absent at these two stations and the Antarctic Intermediate water is present at shallow depths. The salinity maximum in the deep water of this section appears to be about $34.75 \%$ which is considerably less than in the western section where Atlantic Deep Water is present.

The eastern section $J^{\prime}$ extends in a northwest to southeast direction and shows the great uniformity of the Central water Mass in the southeast Indian Ocean. Station locations are given in. 
Table 9. Except for the two northernmost stations all stations appear to be within the Central Water Mass. At the two northern stations relatively fresh water at subsurface depths is similar to the subsurface water in the Indo-Australian Basin and at intermedlate depths below the subsurface layer Arabian Sea Influence is evident from the higher salinity compared to the other stations. Deep water in this section is similar to the deep water in the central section. 


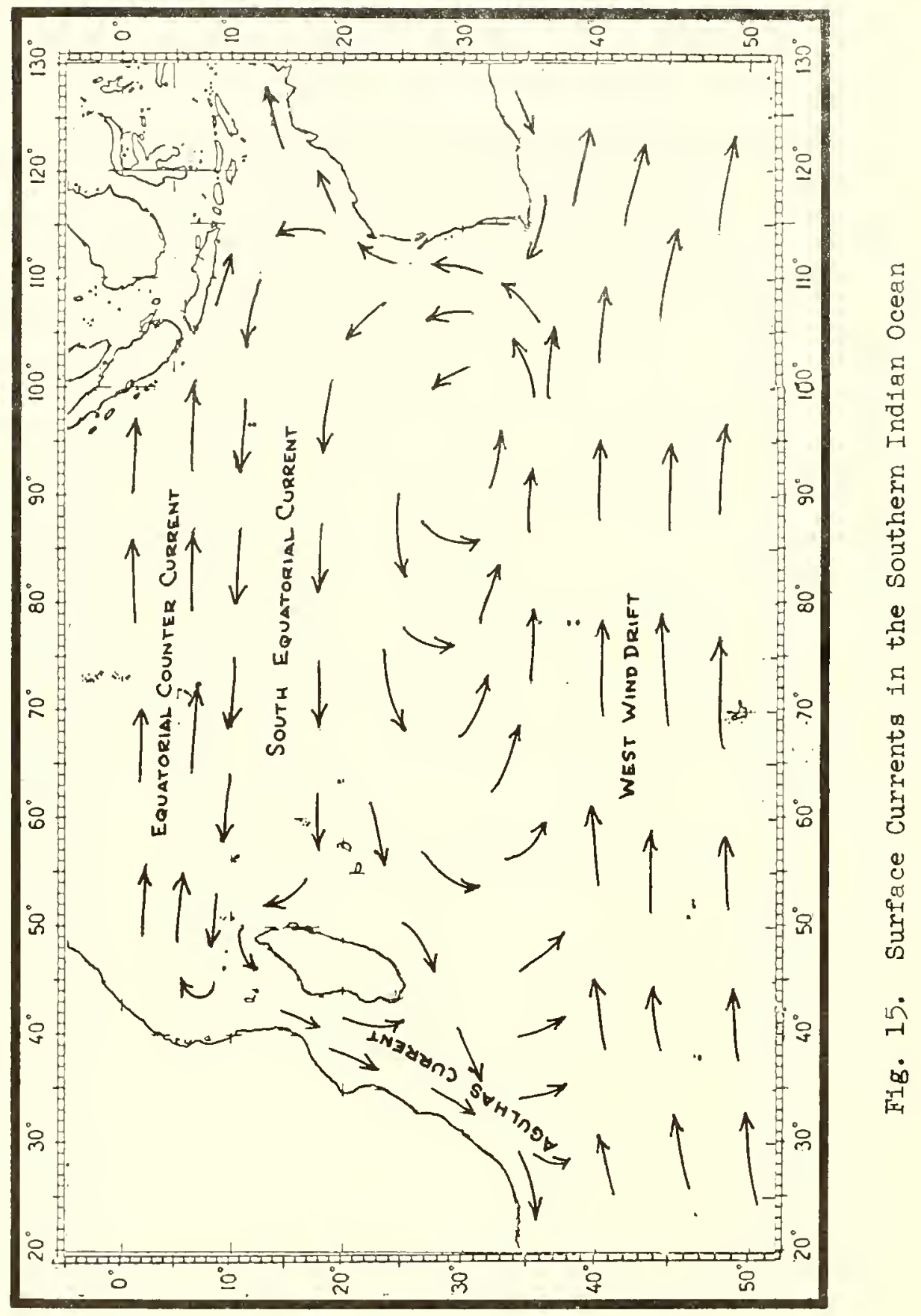


SOUIHERN INDIAN OCEAN

WESTERN SECPION

NODC Consec.

\begin{tabular}{|c|c|c|c|c|c|}
\hline Symbol & Cruise No. & No. & Coordinates & Ship & Year \\
\hline$x$ & 31184 & 224 & $\begin{array}{l}05^{\circ} 00^{\prime} \mathrm{N} \\
53^{\circ} 03^{i} \mathrm{E}\end{array}$ & ARGO & 1963 \\
\hline 0 & 31269 & 017 & $\begin{array}{l}01^{\circ} 10^{\prime} \mathrm{S} \\
48^{\circ} 31^{\circ} \mathrm{E}\end{array}$ & ARGO & 1964 \\
\hline 0 & 90010 & 175 & $\begin{array}{l}50^{\circ} 45^{\prime} \mathrm{S} \\
44^{\circ} 51^{\prime} \mathrm{E}\end{array}$ & VITYAZ & 1960 \\
\hline$\nabla$ & 68001 & 0.37 & $\begin{array}{l}15^{\circ} 28^{\prime} \mathrm{S} \\
42^{\circ} 08^{\prime} \mathrm{E}\end{array}$ & $\begin{array}{l}\text { ATMIRANTE } \\
\text { I.ACERDA }\end{array}$ & 1964 \\
\hline$\square$ & 68001 & 015 & $\begin{array}{l}22^{\circ} 02^{\prime} \mathrm{S} \\
39^{\circ} 09^{\prime} \mathrm{E}\end{array}$ & $\begin{array}{l}\text { AIMIRANIE } \\
\text { LACERDA }\end{array}$ & 1964 \\
\hline$\otimes$ & 74039 & 253 & $\begin{array}{l}28^{\circ} 42^{\prime} \mathrm{S} \\
39^{\circ} 07^{\prime} \mathrm{E}\end{array}$ & DISCOVERY II & 1935 \\
\hline$\Delta$ & 91040 & 012 & $\begin{array}{l}36^{\circ} 21^{\prime} \mathrm{S} \\
33^{\circ} 45^{\prime} \mathrm{E}\end{array}$ & NAIAL & 1962 \\
\hline$\forall$ & 31834 & 002 & $\begin{array}{l}36^{\circ} 39^{\circ} \mathrm{S} \\
23^{\circ} 28^{\prime} \mathrm{E}\end{array}$ & VEMA & 1958 \\
\hline
\end{tabular}


TABLE 8.

\section{SOUTHERN INDIAN OCEAN \\ CEITRAI SECTION}

\begin{tabular}{|c|c|c|c|c|c|}
\hline Symbol & $\begin{array}{c}\text { NODC } \\
\text { Cruise No. }\end{array}$ & $\begin{array}{c}\text { Consec. } \\
\text { No. }\end{array}$ & Coorainates & Ship & Year \\
\hline$\square$ & 31184 & 058 & $\begin{array}{l}00^{\circ} 57^{\prime} \mathrm{S} \\
62^{\circ} 19^{\prime} \mathrm{E}\end{array}$ & ARGO & 1962 \\
\hline$x$ & 31184 & 110 & $\begin{array}{l}05^{\circ} 50^{\prime} \mathrm{S} \\
66^{\circ} 36^{\prime} \mathrm{E}\end{array}$ & ARGO & 1962 \\
\hline 0 & 31834 & 011 & $\begin{array}{l}13^{\circ} 22^{\prime} \mathrm{S} \\
64^{\circ} 40^{\prime} \mathrm{E}\end{array}$ & VFMA & 1958 \\
\hline$\triangle$ & 90830 & 129 & $\begin{array}{l}22^{\circ} 28^{\prime} \mathrm{S} \\
64^{\circ} \mathrm{O} 2^{\prime} \mathrm{E}\end{array}$ & $O B$ & 1956 \\
\hline$\theta$ & 35579 & 029 & $\begin{array}{l}37^{\circ} 39^{\prime} \mathrm{S} \\
62^{\circ} 10^{\prime} \mathrm{E}\end{array}$ & $\begin{array}{l}\text { Various } \\
\text { Ships }\end{array}$ & 1956 \\
\hline$\otimes$ & 35579 & 033 & $\begin{array}{l}46^{\circ} 00^{\prime} \mathrm{S} \\
67^{\circ} 12^{\prime} \mathrm{E}\end{array}$ & $\begin{array}{l}\text { Various } \\
\text { Ships }\end{array}$ & 1956 \\
\hline$\diamond$ & 31184 & 118 & $\begin{array}{l}51^{\circ} 06^{\prime S} \mathrm{~S} \\
65^{\circ} 51^{\prime} \mathrm{E}\end{array}$ & ARGO & 1962 \\
\hline
\end{tabular}


SOUTHERN INDIAN OCEAN

EASTERN SECTION

NODC Consec.

\begin{tabular}{|c|c|c|c|c|c|}
\hline Symbol & Cruise No. & No. & Coordinates & Ship & Year \\
\hline$x$ & 90032 & 088 & $\begin{array}{l}10^{\circ} 41^{\prime} \mathrm{S} \\
70^{\circ} 59^{\prime} \mathrm{E}\end{array}$ & VITYAZ & 1960 \\
\hline$\triangle$ & 31599 & 014 & $\begin{array}{l}14^{\circ} 00^{\prime} \mathrm{S} \\
78^{\circ} 03^{\prime} \mathrm{E}\end{array}$ & EASIWIND & 1961 \\
\hline 0 & 31181 & 011 & $\begin{array}{l}18^{\circ} 53^{\circ} \mathrm{S} \\
88^{\circ} \mathrm{O} 2^{\prime} \mathrm{E}\end{array}$ & ARGO & 1960 \\
\hline$\forall$ & 09004 & 009 & $\begin{array}{l}25^{\circ} 34^{\prime} \mathrm{S} \\
95^{\circ} 12^{\prime} \mathrm{E}\end{array}$ & DIAMANTINA & 1960 \\
\hline$\otimes$ & 09001 & 045 & $\begin{array}{r}29^{\circ} 37^{\circ} \mathrm{S} \\
104^{\circ} 41^{\circ} \mathrm{E}\end{array}$ & DIAMANTINA & 1959 \\
\hline$\square$ & 09002 & 030 & $\begin{array}{r}36^{\circ} 56^{\circ} \mathrm{S} \\
114^{\circ} \mathrm{O} 4^{\circ} \mathrm{E}\end{array}$ & DIAMANIINA & 1960 \\
\hline$\nabla$ & 09001 & 002 & $\begin{array}{r}35^{\circ} 22^{\prime} \mathrm{S} \\
128^{\circ} 31^{\prime} \mathrm{E}\end{array}$ & DIAMANTINA & 1959 \\
\hline
\end{tabular}




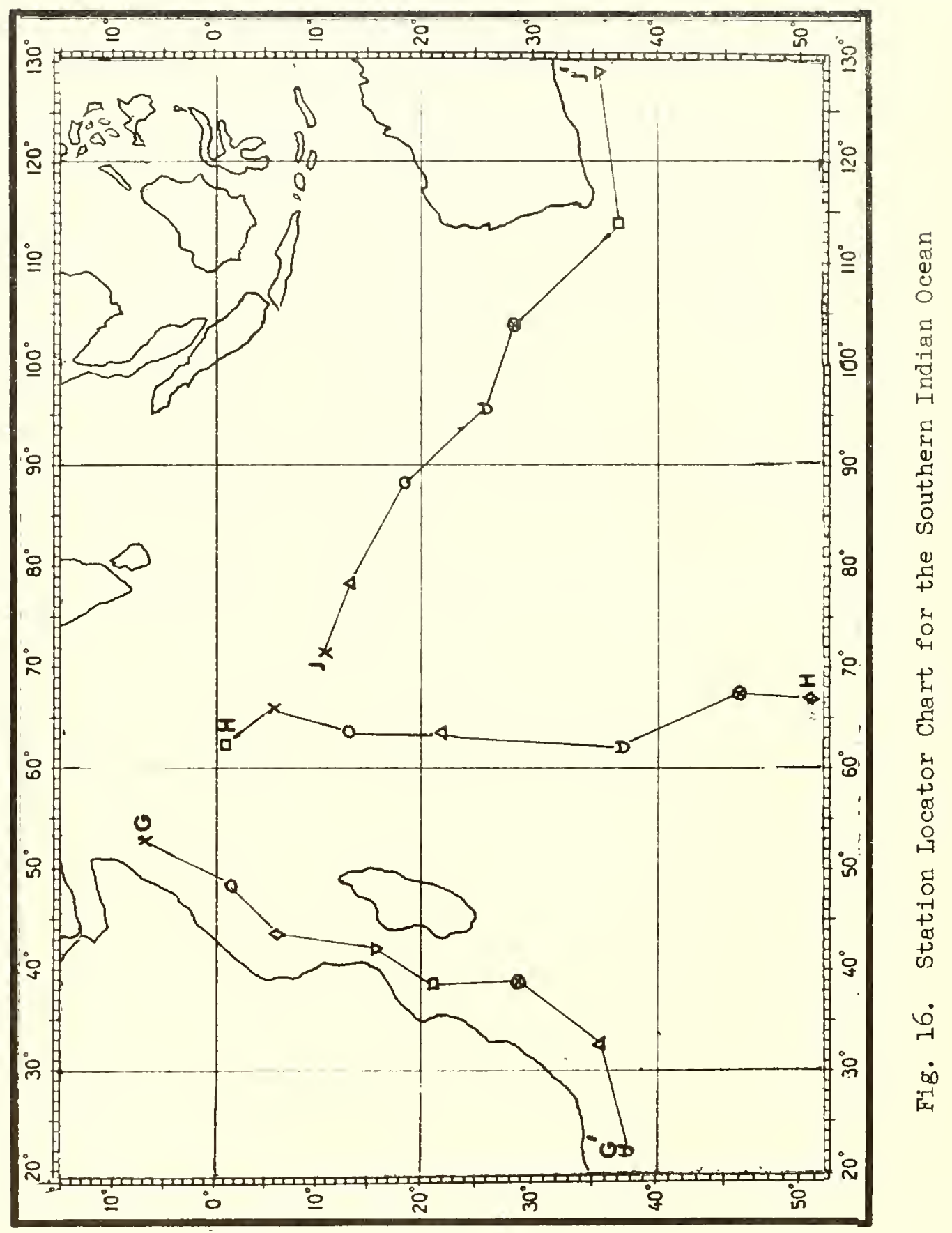




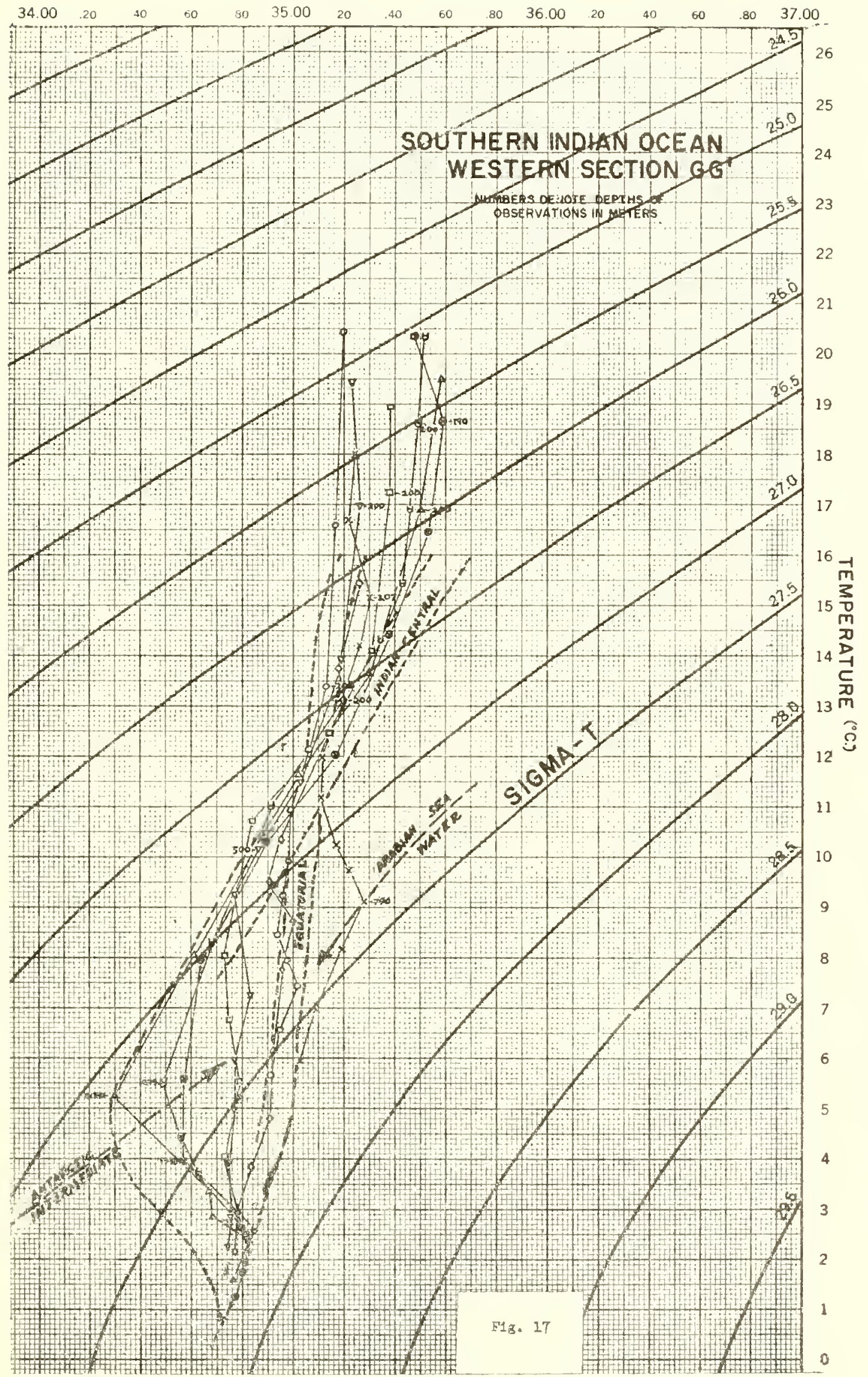




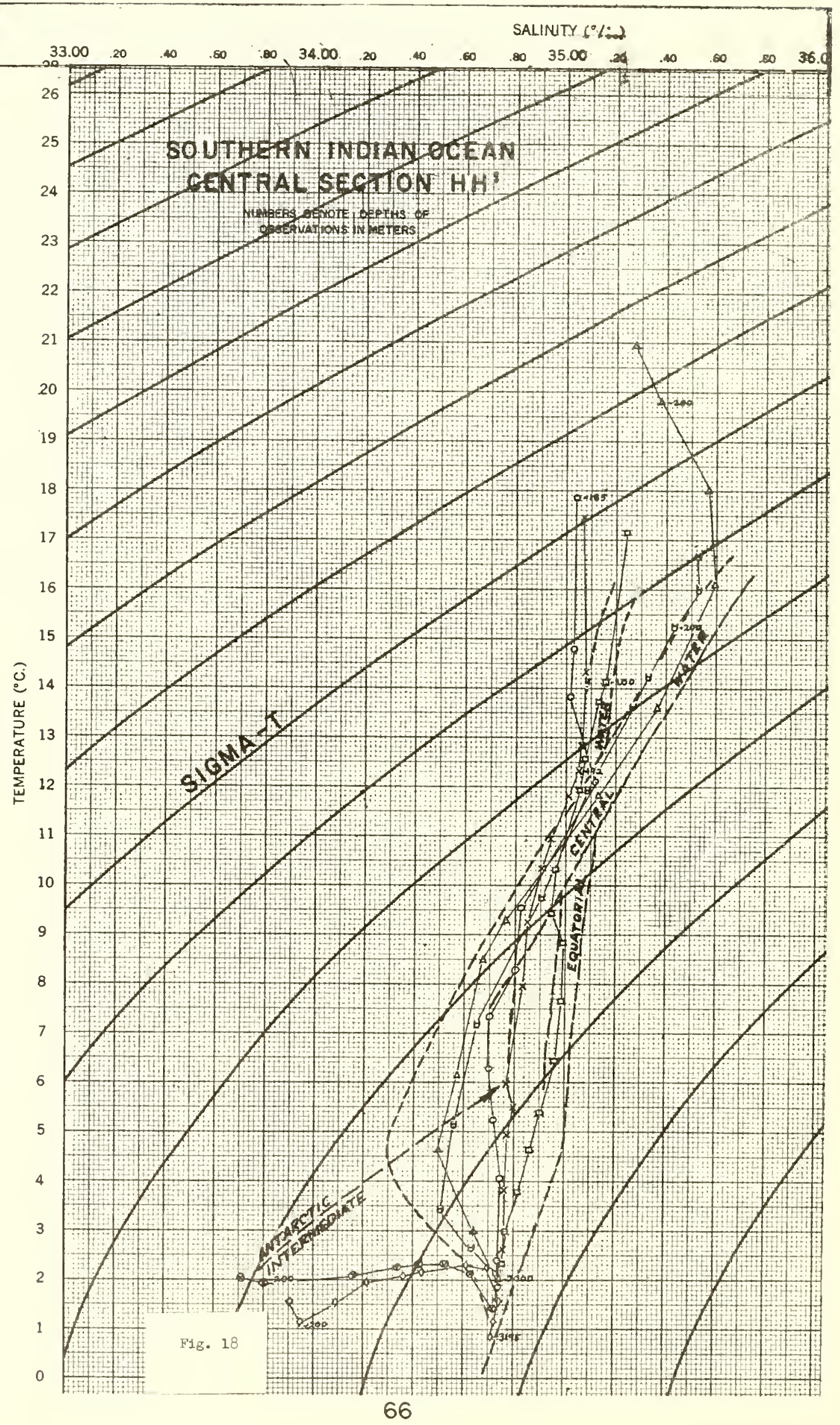




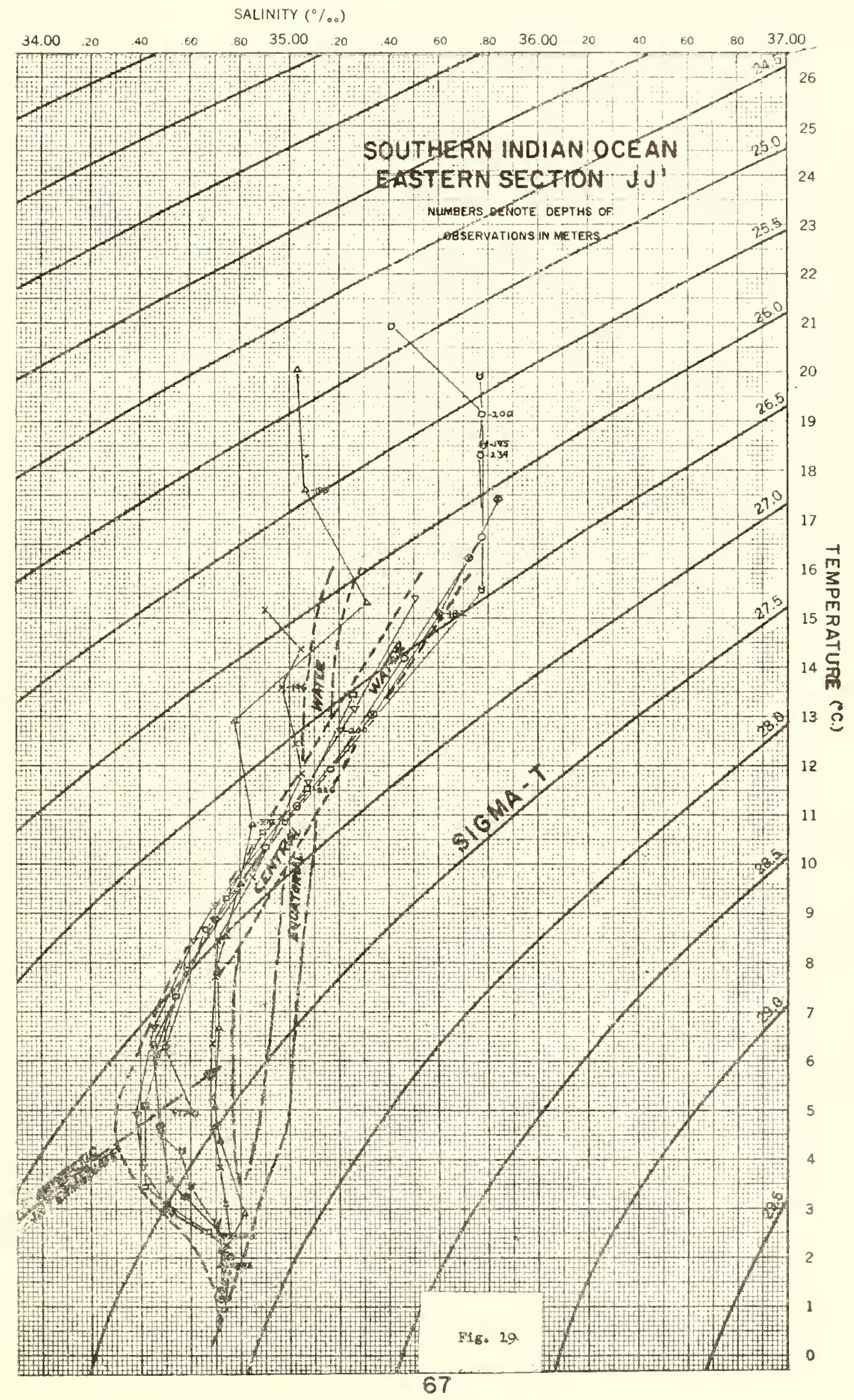


The peculiarities of hydrological conditions in the Indian Ocean are the direct result of its geographical position. The great land mass of Asia which encloses it in the northern tropical region produces monsoonal conditions which are unparalieled in other world oceans. In addition to this, the proximity to vast arid regions in the northwest which Includes the Red Sea and Persian Gulf results in water of unusually high temperature and high salinity in the Arabian Sea. In contrast, on the eastern side of the ocean in the region between Indonesia and Australia, unusually low salinity water is present as a result of high precipitation and inflow from the Pacific. Cold polar water is not accessible to the Indian Ocean from the north as in the Atlantic and Pacific Oceans and the only source of cold water is from the Antarctic region to the south.

North of the Equator the surface circulation is in direct accordance with the seasonal monsoons and the North Equatorial Current is not a permanent circulation feature as in the Atlantic and Pacific Oceans.

South of the Equator the circulation pattern is similar for the most part to that which exists in the South Atlantic and South Pacific Oceans. The principal difference is that in the Indian Ocean the large central gyre is displaced farther toward the south than in the other oceans. Even the Subtropical Convergence is displaced toward the south in the Indian Ocean. The South Equatorial Current and the Equatorial Counter Current are present during all seasons. The West Australian Current which llows north along the coast of Australia is rot a weli-developed current and is dispersed in the 
Trade Wind Zone by the South Equatorial Current. The Agulhas

Current on the easterm side is a strong deep current.

The fact that the continental boundaries do not extend far to the south allows a great exchange of water at all depths with the Pacific and Atlantic Oceans. On the Atlantic side there is a net inflow of water and on the Pacific side an outflow.

Indian Ocean Central water is formed by sinking at the Subtropical Convergence and spreads at subsurface depths toward the Equator. It reaches its farthest northern extension on the western side of the ocean where it is found at about $10^{\circ} \mathrm{S}$ latitude. The Antarctic Intermediate Water is formed at the Antarctic Convergence and also spreads northward toward the Equator where it is gradually forced to the surface by the North Indian Deep Water which is formed In the Equatorial region. The North Indian Deep Water is warm and saline, being formed by an admixture of Arabian Sea Water. This deep water finds its way to the south and surfaces in the Antarctic region distributing heat from north to south. North Indian Deep Water is found in practically all parts of the Indian Ocean although in the southwest corner Atlantic Deep Water is also present to a limited degree. Antarctic Bottom Water, which forms by sinking from the surface along the continental slope of Antarctica, is called Indian Ocean Bottom Water after it passes from the Antarctic Basin Into the Indian ocean. This bottom water spreads along the ocean floor on both sides of the Mid-oceanic Ridge and into the Arabian Sea and Bay of Bengal. Bottom water is the coldest of all water masses below the surface layer.

Deep and bottom waters are distributed evenly over the entire expanse of the ocean and possess great homogeneity. They undergo 
only gradual modification from the southern to the northern Iimits of the ocean. Of the waters below the surface layer the subsurface water masses are the most Iimited in spatial extent and remain within well defined areas of the ocean. With this in mind, the areal limits of the principal subusrface water masses of the Indian Ocean are designated on the accompanying chart (Fig. 20). As an additional ald in locating the extent of these water masses the chart bears Marsden Square numbers, which are numbers assigned to each $10^{\circ}$ square of latitude and longitude. It can be seen that the Laccadive Island RIdge affords a sharp division between Equatorial Water on the west and Indo-Australian Subsurface Water to the east. The Indo-Australian Water is apparently carried west by the South Equatorial Current until it meets the barrier of the ridge and is then deflected southward. The Equatorial Water also follows the ridge south for some distance. Farther to the north the Equatorial Water finds its way across the ridge and proceeds into the Bay of Bengal and part way along the coast of Sumatra.

The division between Equatorial Water and Arabian Sea Water is not so well defined, as these two water masses have many properties In common. The Equatorial Water in one sense can be considered the end product of the modification of Arabian Sea Water with distance from the Red sea and Persian Gulf. It is defined as a separate water mass here because $1 t$ is more homogeneous and does not display the rapid change in salinity with distance which is so characteristic of the Arabian Sea.

In the transition zone south of the Equatorial Water Mass both Equatorial and Indian Central Water are found. Even farther south In the area of the Central Water Mass the influence of Equatorial 
Water may be detected as a salinity maximum within the Central Water Mass column. This is commonly called the Red Sea influence and 1 is quite pronounced along the coast of Africa north of the Mozambique Channel.

The delineation of water mass boundaries as presented in Figure 20 represents in broad outine the extent of the subsurface waters. As more data from the International Indian Ocean Fxpedition is processed and made avaliable, it will be possible to confirm these boundaries in greater detail. 


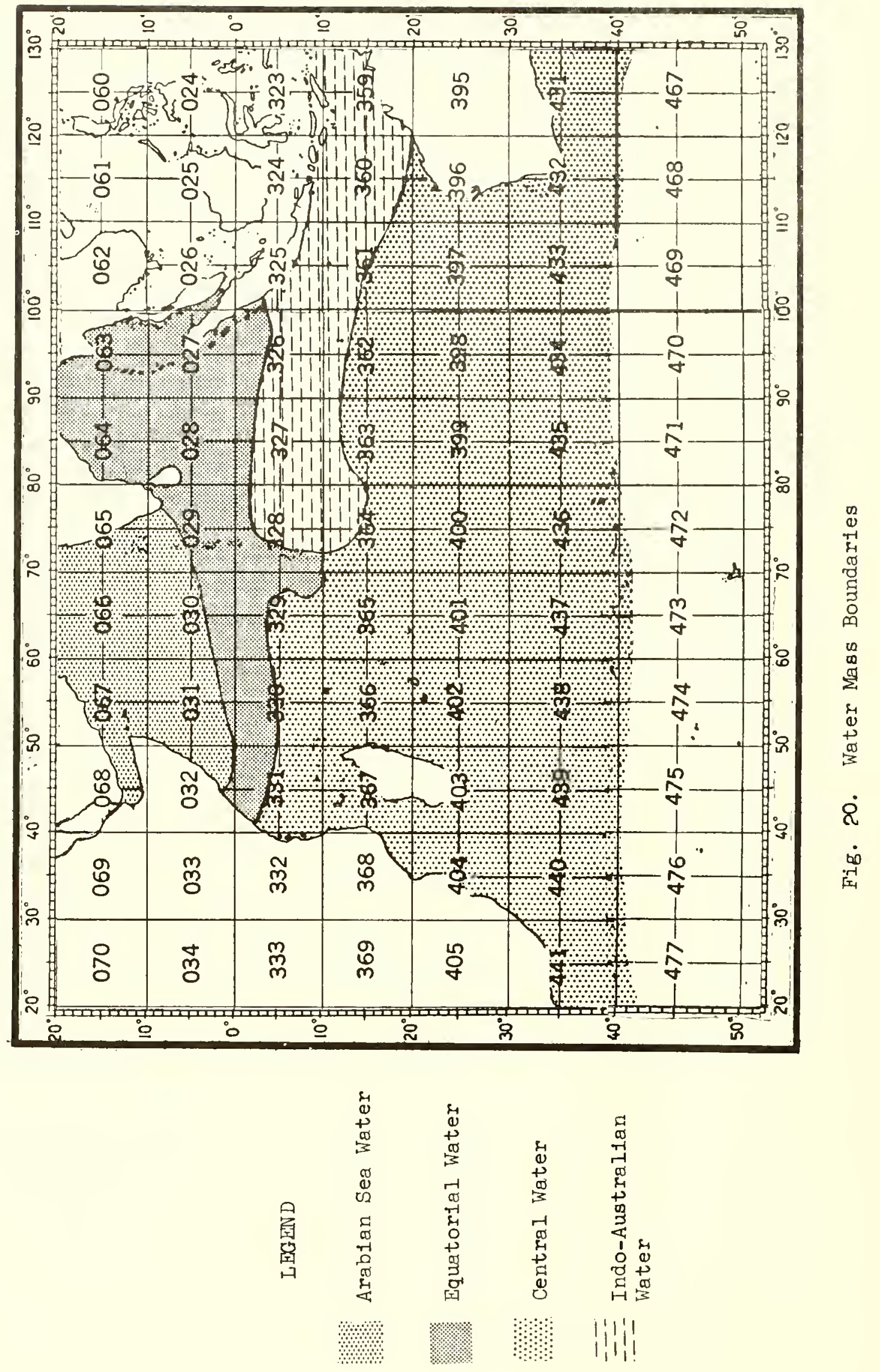


Bezrukov, P. I. "Investigations in the Indian Ocean on the 33 rd Cruise of the Expeditionary Vessel V1tyaz," trans. Okeanologiya, I (4). Moscow: 1961.

Carlsberg Foundation. Oceanographic Expedition around the World. London: Oxford UnIversity Press, 1932.

Carruthers, Dr. J. W., S. S. Gogate, J. R. NaIdn, and T. Laevastu. "Shoreward Upslope of the Layer of Mintmum Oxygen off Bombay," Nature, CXXCIII (Apr11 18, 1959).

Dubach, Harold $W$. A Summary of Temperature-Salinity Characterist1cs of the Persian Gulf, NODC Publication G-4. Washington: U. S. Naval Oceanograph1c Off1ce, 1964.

The John Murray Expedition 1933-34. Sc1entif1c Reports, I. London: 1935.

La Fond, E. C. "On the Circulation of the Surface Layers off the East Coast of India," Andhra University Memolrs in Oceanography. Walta1r: Andhra UnIversity, 1958.

Ie Pichon, Xavier. "The Deep Water C1rculation in the Southwest Indian Ocean," Journal of Geophysical Research (December, 1960).

Möller, Lotte. Deep Sea Circulation in the Indian Ocean. Hamburg: 1933.

Muromtsev, A. M. Basic Outline of the Hydrology of the Indian Ocean. Leningrad: $1 \overline{959 .}$

Orren, M. J. "Hydrological Observations in the South West Indian Ocean," Collected Reprints of the International Indian Ocean Expedition. Bruges: St. Augustin Press, 1965.

P1ckard, George I. Descriptive Phys1cal Oceanography. New York: The MacMillan Company, 1963.

P1lot Chart of the North Pacific Ocean No. 1401. "Currents of the Arablan Sea" on reverse side. Washington: U. S. Hydrographic office, June 1956.

Re1chs-Marine amt. Expedition of S.M.S. Planet, 1906-07. Berlin: S1gismund, 1909 .

Rochford, D. J. "Hydrology of the Indian Ocean," Australian Journal of Mar1ne and Freshwater Research, XII (1961), pp. 129-149.

- "Hydrology of the Indian Ocean," Australlan Journal of Marine and Freshwater Research, XIII (December, 1962), pp. $226-251$.

Salling Directions for the Bay of Bengal. H.0. Pub. No. 64, 4th Ed. Washington: 1951. 
Schott, G. Geographie des Indischen und Stillen Ozeans. Hamburg: Boysen, 1935 .

Spry, William. Cruise of Her Majesty's Ship Challenger. Lonäon: Low, Marston, Searle, and Rurington, 1877.

Svenska djupharsexpeditionem. Reports edited by Hans Pettersson. Goteborg: Elenders boktr., 1951.

Sverdrup, $\dot{H}$. V., Martin W. Johnson, and Richard H. Fleming. The Oceans. Englewood Cliff's, N. J.: Prentice-Hall, Inc., $\overline{1942 .}$

Tchernia, P., H. Lacombe, and P. Guibout. "Some New Hydrological Observations in the Equatorial Region of the Indian Ocean"; France, Bulletin d'Information, X(3) (March 1958), pp. 115-143.

United Nations Educational, Scientific and Cultural Organization.

"Development of the International Indian Ocean Expedition," Collected Reprints of the International Indian Ocean Expedition. Bruges: St. Augustin Press, 1965.

Wyrtki, Klaus. "Physical Oceanography of the Southeast Asian Waters," NAGA Report, II. La Jolla, California: Scripps Institution of oceanography, 1961.

- "Geopotential Topographies and Associated Circulation in the South-Eastern Indian Ocean," Australian Journal of Marine and Freshwater Research, XIII (June 1962), pp. 1-17. 



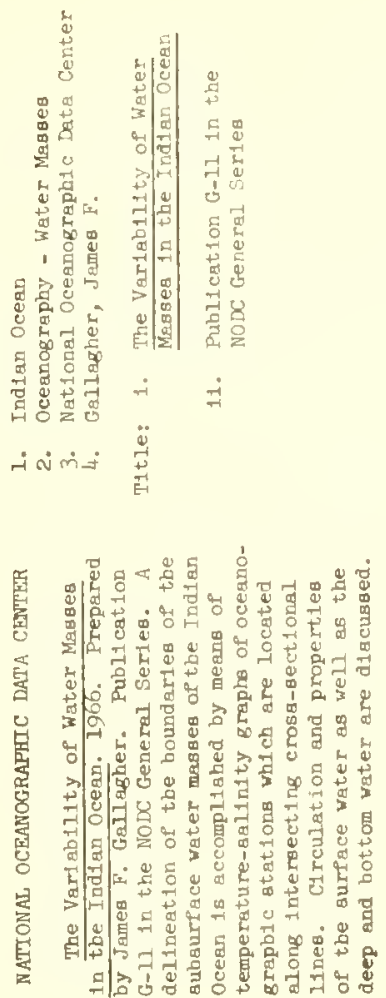
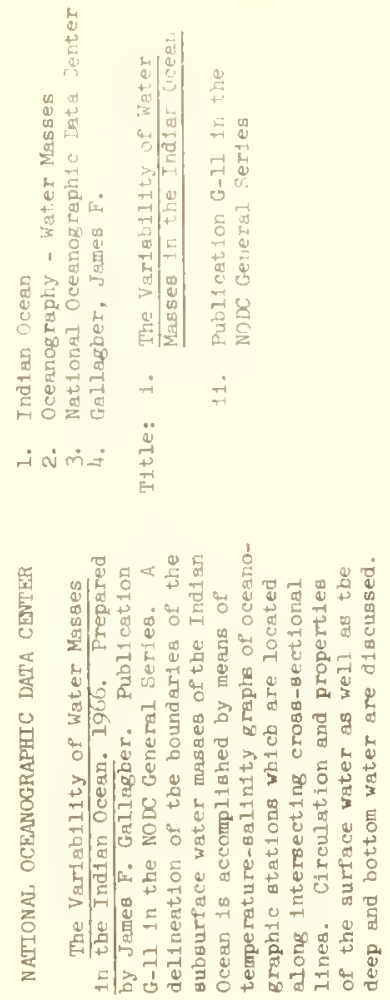
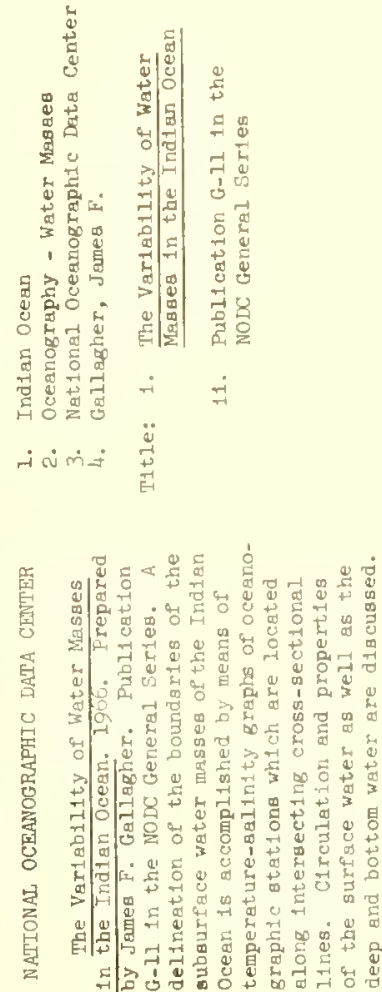
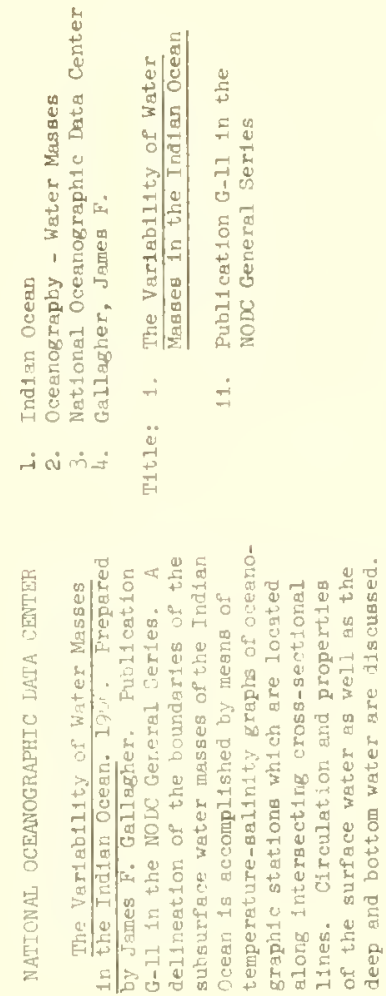


